\title{
Determinants of urban sprawl in Latin America: evidence from Santiago de Chile
}

\section{Cristian Silva $^{1}$ (D) Francisco Vergara-Perucich ${ }^{2}$}

Received: 13 January 2021 / Accepted: 8 June 2021 / Published online: 27 July 2021

(c) The Author(s) 2021

\begin{abstract}
Urban sprawl has been widely discussed in regard of its economic, political, social and environmental impacts. Consequently, several planning policies have been placed to stop—or at least restrain-sprawling development. However, most of these policies have not been successful at all as anti-sprawl policies partially address only a few determinants of a multifaceted phenomenon. This includes processes of extended suburbanisation, peri-urbanisation and transformation of fringe/belt areas of city-regions. Using as a case study the capital city of Chile-Santiago-thirteen determinants of urban sprawl are identified as interlinked at the point of defining Santiago's sprawling geography as a distinctive space that deserves planning and policy approaches in its own right. Unpacking these determinants and the policy context within which they operate is important to better inform the design and implementation of more comprehensive policy frameworks to manage urban sprawl and its impacts.
\end{abstract}

Keywords Urban sprawl · Urban development · Suburbanisation · Planning policy · Santiago de Chile

\section{Introduction}

Cities have emerged as keystones within global policies towards sustainable development. United Nations (UN) projections indicate that urban population will be increased by 2050 (UN 2017). Cities are identified as one of the main drivers of

Cristian Silva

c.silva@qub.ac.uk

Francisco Vergara-Perucich

jvergara@udla.cl

1 School of Natural and Built Environment, Queen's University Belfast, David Keir Building, Stranmillis Road, Belfast BT9 5AG, UK

2 Chair of the Centre for the Production of the Space, Universidad de Las Américas, Campus Providencia, Manuel Montt 948, Providencia, Chile 
environmental change and energy consumption (Gargiulo and Russo 2017; Watts 2017). Against this backdrop, the UN's New Urban Agenda (UN Habitat III 2017) has framed ambitious global goals for sustainability in which cities are highlighted as pathways to sustainable development. This aspiration is captured within the Sustainable Development Goals (SDGs) — specifically the SDG11—clearly aligned with social and environmental sustainability theories. SDG target 11.6 indicates that a substantial reduction of 'environmental impact of cities, including by paying special attention to air quality and municipal and other waste management', must be achieved by 2030. Target 11.a makes an explicit claim on the importance of having 'positive economic, social, and environmental links between urban, peri-urban and rural areas' by strengthening planning at national and regional levels. Target 11.b advocates for having efficient mitigation and adaptation plans to climate change and resilience to disasters by strengthening local governments (UN 2017). However, in this scenario, one of the main threats that cities face to achieve these goals is 'urban sprawl.' Traditionally related to low-density suburbia, urban sprawl can also be 'compact' (Ståhle 2008), spatially diverse and functionally multifaceted (DunhamJones and Williamson 2009,). In all these instances, the presence of different interstitial spaces that contribute to land fragmentation also become constitutive of urban sprawl (Phelps and Silva 2017).

Urban sprawl differentiates from 'suburbia' (characterised by the production of low-density residential neighbourhoods) and 'peri-urbanisation' (mainly focussed on the transformation of fringe-belt areas and the urban-rural transect), as it defines a specific pattern of urban growth that embraces both processes of suburbanisation and peri-urbanisation, but also dispersion of infrastructure interspersed with farming and vacant lands. The understanding of urban sprawl used in this paper adheres to Sieverts' notion of the Zwischenstadt (Sieverts 2003), wherein all the aforementioned elements configure a distinctive geographical space in which rural, industrial, infrastructural, residential, and interstitial lands coexist; a geography of interrelation between the proper city and the open countryside (ibid: 2003). While Sievert's Zwischenstadt clarifies the geographical scope of urban sprawl, it is characterised by the scattered expansion of residential developments, encroachment of rural lands, environmental fragmentation, high rates of car-dependency, inorganic expansion of urban boundaries, the presence of different interstitial spaces, concentration of peripheral poverty, and saturation of local services (Altieri et al. 2014; Jaret et al. 2009; Phelps and Silva 2017; Romero and Órdenes 2004). There is a broad-based consensus that urban sprawl is an unsustainable pattern of urban development with impacts elucidated in what Bruegmann (2005) identified in the first, second, and third 'anti-sprawl campaigns'. These impacts include the costs of sprawl, social problems, environmental objections, limits to urban growth, car-dependency, inefficient land-uses, encroachment of rural lands, sociospatial segregation, and effects at global scales linked to climate change (Bruegmann 2005). Further impacts include correlations between car-dependency and higher rates of obesity (Wu et al. 2020), traffic congestion, inner-city decay, high rates of energy consumption, transportation costs, air pollution, reduction of environmental services, inefficient land-uses, and adverse impacts on social capital inter alia (Hamidi and Zandiatashbar 2019). 
Since the 1920s, several planning policies have been implemented to address these impacts, usually translating into restrictions to urban growth such as the 'urban limits' (Grimes and Liang 2009), 'green belts' (Dockerill and Sturzaker 2019), and 'urban growth boundaries' (Grimes and Liang 2009). However, in addition to being ineffective, these planning approaches, in many cases, have leapfrogged development and land fragmentation (Amati 2016). Alternatively, narratives of retrofitting and compactness have emerged as more preventive; 'these ideas form something of a Zeigeist in architectural, design and planning circles' (Phelps 2015, p. 43) for attracting city-like functions and qualities. These policies have fed anti-sprawl narratives along with "the rise of new planning mantras such as "sustainable", "compact" or "zerocarbon" development' (Phelps 2012, p. 172). However, the underlying problem is that urban sprawl is much a product of modernists-inspired nations where their capital cities reflect projects of national development. This modernisation is seen as being driven by the values of the neoliberal agenda that has reached transnational implications since these values have become embedded in the politics and praxis of governments, institutions and organisations-at all levels of spatial governance - around the globe' (Boland et al. 2017). Thus, despite the apparently 'natural' (or spontaneous) emergence of sprawling growth, 'it has been thoroughly planned as a result of interventions by all ties of government' (Phelps 2015, p. 40).

Against all predictions, 'urban sprawl has become a global phenomenon as an outcome of growing population and rapid urbanization' (Pawe and Saikia 2020, p. 226). As such, urban sprawl remains one of the most longstanding patterns of urban development and a permanent structure of cities in the aftermath of the WWII. Despite this, urban sprawl manifests differently between regions. Studies conducted in Europe describe urban sprawl as more continuous residential expansion and compact peri-urban developments (Ståhle 2008), highly influenced by public policies; 'in Paris, for example, large parts of suburban settlements consisted of high-density houses that were directly built by governmental bodies (...). This procedure was not common in the United States, were private-market, single-family home was the norm' (Patacchini et al. 2009, p. 126). In China, urban sprawl is characterised as leapfrog development in which rural villages, informal settlements, farming spaces and infrastructure of transport coexist with the formal expansion of cities (Deng and Huang 2004). In Africa, urban sprawl also takes the form of leapfrogged development and 'occur in nucleated or clustered pattern where physical development proceeds at the peripheries of cities, often characterised by concentration of people of particular social class or income group' (Cobbinah and Aboagye 2017, p. 233). Here, 'physical development is patchy, dotted and spread out, creating discontinuity in effective urban development' (ibid: 233). In the Australasian context urban sprawl takes a more America form 'characterized by detached houses, domestic carports (usually for two cars or more), roads, street lights, car sale yards, fast-food outlets, shopping malls with large car-parking areas and inner highways' (Silva 2019a, b, p. 2).

As tackling the causes of urban sprawl relates to more structural elements of our societies-including market-driven politics, population growth, the culturally rooted 'suburban dream' and improvements on regional infrastructure and housing affordability (Willing and Pojani 2017) —addressing the determinants of sprawl seems to 
be feasible. In this paper, the notion of 'determinant' is used to analyse the specific factors that explain sprawling growth from a planning perspective-including quantitative, qualitative and context-dependent factors-as well as policy-based causes. Although empirical studies in this regard have been conducted in China (You and Yang 2017; Li and Li 2019), North America (Barrington and Millard 2015), Europe (Oueslati et al. 2015; Pirotte and Madre 2011) and Middle East (Masoumi et al. 2018; Bagheri and Tousi 2018), not much has been researched about the Latin American context and the manner in which it contributes to wider debates on urban sprawl beyond studies on its impacts (Romero and Órdenes 2004). Taking the case of the capital city of Chile-Santiago - the questions raised in this paper point at what the determinants of urban sprawl are, and how they influence Santiago's urban development.

It is hypothesised that planning responses are unable to articulate the whole spectrum of interlinked determinants that drive the sprawling growth of cities, and have difficulties to operate within the specific policy context in which urban sprawl unfolds. What is found in the case of Santiago, is that at least thirteen interlinked determinants drive Santiago's urban sprawl, thus posing significant challenges for urban governance. On this basis, this paper contributes to a more comprehensive understanding of urban sprawl from a Latin American perspective. Although the term 'urban sprawl' has its origins in the Anglo-Saxon literature, case studies from the Global South can contribute to further insights on how urban sprawl is manifested. This is particularly sensitive in Latin America in which sprawling growth reveals clear signs of sociospatial segregation (Cox and Hurtubia 2020), and are often a subject of standardised planning solutions unable to articulate the cultural, historical, socioeconomic, political, and geographical singularities.

In the next section the meanings of urban sprawl are discussed to situate its multifaceted character and the need to unpack its determinants. This provide insights about urban sprawl in both conceptual and empirical terms that are pulled together in a subsequent section wherein the determinants of Santiago's urban sprawl are examined. The conclusions underline the determinants of Santiago's sprawl and the varied ways they define its sprawling suburbia. The values of institutional crosssectoral coordination are also highlighted but most importantly, the need of framing more strategic planning responses where 'the problematic for urban politics is (...) not a question of growth versus no growth - as posited in the classic growth machine model—but rather what kind of growth' (Phelps 2015, p. 45).

The contribution of this paper is twofold. First, it provides further elements to ensure a more comprehensive understanding of urban sprawl and its policy context. These findings link to debates around the production of the space under neoliberalised nation-states and the contradictions of the 'growth machine' (Phelps 2012). Second, the paper unpacks the set of interlinked determinants of urban sprawl that allows the formulation of specific policies to address them more in a more strategic manner. The paper seeks to shed light on understanding urban sprawl beyond simplifications and anti-growth narratives, and how the case of Santiago can better inform the design and implementation of planning solutions aligned with the UN's New Urban Agenda and the SDG11 targets. 


\section{The meanings of urban sprawl and its policy context}

\section{Situating urban sprawl}

The meanings of urban sprawl are contested and differ between morphological, instrumental and policy-based research. In an attempt to define the geographical context of urban sprawl, empirical research suggests that urban sprawl is an all-embracing geography that involves processes of suburbanisation (Charmes and Keil 2015), peri-urbanisation (Ravetz and Loibl 2011) and transformation of fringebelt areas (Whitehand and Gu 2017). Urban sprawl describes a morphology largely characterised by residential neighbourhoods, high levels of car-dependency, single land-uses, and lack of physical continuity (Jaret et al. 2009). This includes land fragmentation and dispersion of infrastructures such as airports, energy plants, and industries (Altieri et al. 2014; Trubka et al. 2010). Urban sprawl is also accepted to embrace developments beyond suburbia, including settlement of different sorts such as 'exurbia' (Bruegmann 2005), 'technoburbs' (Fishman 1987), 'edge cities' (Garreau 1991), ‘edgeless cities' (Lang 2003), 'satellite towns' (Abubakar and Doan 2017) and 'post- suburbs' (Phelps and Wood 2011), all part of Sieverts' Zwischenstadt (2003): a distinctive geography of transition between the proper city and the open countryside (Sieverts 2003). Similarly, Rauws and de Roo's notion of the 'third type of landscape' (2011) is something 'which cannot solely be understood in terms of progressive intensification of urban functions in the rural environment' (Rauws and de Roo 2011, p. 269), but 'be distinguished in terms of its own specific dynamics and characteristics (...), a spatial system in its own right' (ibid: 270).

Instrumental studies propose a 'sprawl index' to identify patterns of urban sprawl by combining different indicators (Wolman et al. 2005). Here, urban sprawl is defined as 'a pattern of land use in an urbanised area exhibiting low levels of some combination of eight distinct dimensions: density, continuity, concentration, clustering, centrality, nuclearity, mixed uses, and proximity' (Galster et al. 2001, p. 685). From this viewpoint, there is not just 'one' urban sprawl but 'many', as it can differ from region to region regarding differences in these criteria (Li et al. 2020). Different areas of the same city can also show different levels of sprawling growth, in which some areas can be more (or less) sprawling than others. Hess (2001) argues that what can be seen as a compact city can be a very sprawling one in the future: it is the trend in population density, rather than current population density, that determines whether a city is sprawling or not. A city becoming less densely populated through time is said to be sprawling, even if it is currently quite densely populated in comparison to other cities' (Hess et al. 2001, p. 6). On this basis, urban sprawl cannot be reduced to a static view of a city. Instead, it must be seen as 'a continuous process of urban transformation which functions more like a verb than a noun' (Silva 2019a, b, p. 58), and can illustrate different dynamics, even within the same city-region. As such, urban sprawl can also be observed in small towns and villages - making it a non-exclusive condition of megacities (Horn and van Eeden 2018) — which raises further reflections around its intrinsic negative connotation. 
According to theoretical research, the underlying assumption that urban sprawl is an 'urban' issue limits its implications at regional levels (Osman et al. 2016). Urban sprawl is usually filtered through urban theories focussed on intensive processes of 'the production of the space' (Brenner and Elden 2009) as synonym of 'built-up' space. This leaves aside the varied spectrum of rural, undeveloped, vacant and interstitial spaces that lie between developments (Silva 2019a, b). However, urban sprawl is corseted by existing (and somehow obsolete) analytical containers of the 'urban' that minimise its comprehension from rural and regional theories. This undermines the inter-institutional relevance of sprawling processes 'that are administratively urban but retain their rural structure and characteristics' (Qian and Wong 2012, p. 409).

\section{The policy context of urban sprawl}

Urban sprawl is associated with processes of extended suburbanisation started in North America within the economic recovery after the WWII. Indeed, the term 'urban sprawl' appeared in the 1940s (Gillham 2002) to explicate the American suburbanisation driven by the increasing use of private cars and the expansion of the interstate motorway system (Soule 2006). It has been demonstrated that oil companies strongly campaigned for the use of private cars (and thus, oil), the extensions of motorways, the reduction of public transport, and the consolidation of the 'suburban dream' as synonym of personal freedom (Phelps 2015; Hamel and Keil 2015). Notably, since the 1970s urban sprawl — rather than being natural or spontaneous-it has been thoroughly planned (Gottdiener 1977) as the unintended consequence of underlying politics of modern capitalism (Beck et al. 2003). Here, the environmental and social effects of sprawl 'have been as much a product of the state as of the private sector' (Phelps 2015, p. 4), given that public and private sectors have become barely distinguishable. In this context, the policy factors that promulgated urban sprawl relate to land-use conversion, population change, traffic and vehicle miles travelled, energy consumption and fiscal measures (Nelson 1999).

Since its origins urban sprawl has been evolving in terms of its spatial, economic, social, and functional composition, different studies have examined the emergence of suburban employment nodes, emerging patterns of polycentricity, multi-functionality, as well as economic and functional self-sufficiency (Phelps and Wood 2011; Burger and Meijers 2012). The latter determines the 'post-suburban' nature of suburbia characterised by a more balanced employment and residential linkage (Phelps 2015). These changes were detected by Calthorpe and Fulton (2001), who observed that 'since their creation, the suburbs have been evolving and changing. From bedroom communities to edge cities, the trend has been toward more complex and complete places' (Calthorpe and Fulton 2001, p. 198). Similarly-and on the basis of how Oslo has defined its sprawling space-Røe and Saglie (2011) put forward a model for urban sustainability through the consolidation of suburban "minicities; a constellation of interconnected districts characterised by a mix of residential 
land-uses, workplaces, housing typologies, public amenities, transportation and public spaces with comparatively higher indicators of urban quality (Røe and Saglie 2011).

Accordingly, it is possible to indicate that there is no single definition of urban sprawl as they differ from morphological, instrumental, and policy-based research. It is also apparent that urban sprawl operates through belated implementation of landuse plans that leave policies of control behind de facto urbanisations (Sharifi et al. 2014; Phelps 2012). Although urban sprawl somehow mimics the morphologies of the spatially homogeneous 'suburbia', it also describes a random assemblage of shapes, infrastructures and functions that suggest a diverse space of experimentations in planning beyond bi-dimensional zoning (Gallent and Shaw 2007).

In light of these conceptual gateways, the operational understanding of urban sprawl used in this paper relates to the geographical scope proposed by Sieverts' Zwischenstadt (2003), which situates urban sprawl as the multifaceted and distinctive space of transition between the consolidated city and the open countryside. This (in-between) space of transition varies from and one region to another regarding how different policy frameworks define 'the city' and 'the rural' and in essence, the magnitude and scope of the 'in-between.' Nonetheless, bounding these geographies becomes significant considering its practical implications in planning (Fig. 1).

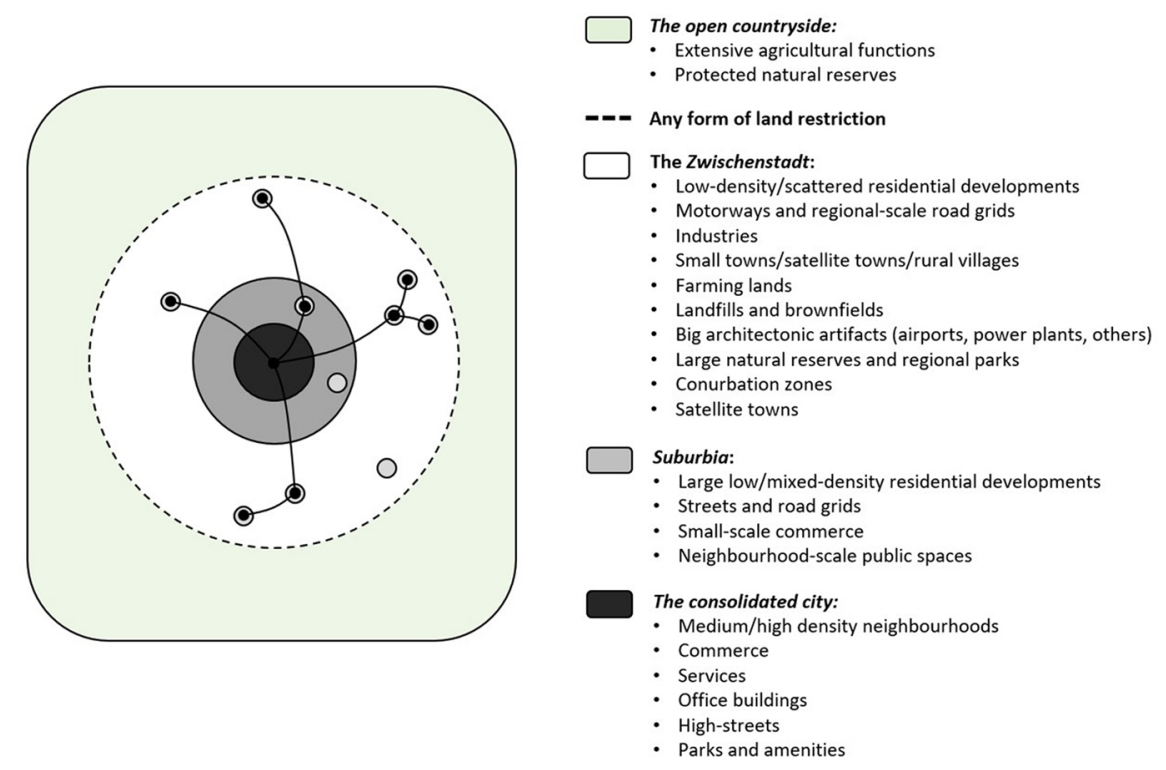

Fig. 1 Geographical scope of urban sprawl (author's diagram) 


\section{Determinants of urban sprawl}

The literature about the determinants of urban sprawl is specific to the context where it is examined. In European cities, these determinants relate to population growth, housing demands, land-market constraints as well as improvements in infrastructure (Oueslati et al. 2015; Pirotte and Madre 2011). It is noteworthy that these studies are limited to monocentric city models with clear correlations between land fragmentation and income growth (that derives into higher rates of car use). Considering the extant debate about determinants of urban sprawl, these can be classified into physical and geographical, social, and policy-based determinants.

\section{Physical and geographical determinants}

In the case of China, Li et al. (2020) demonstrated that driving forces of urban sprawl differ across spatial scales. The authors argue that transport and water supply influence at prefectural and county levels, while the influence of GDP, nonagricultural population growth, institutional arrangements and foreign investments are at a regional level. The study concluded that the hierarchical governance and the socioeconomic and political determinants assume greatest significance (Li et al. 2020). In a geographical analysis of American cities, physical constraints for continuous development and the value of open space are the main determinants of urban sprawl. It relates to the concentration of employment at the 'central business district' (CBD). The latter is surrounded by suburbia that results from the trade-off between convenient commuting, affordable housing and the low-cost of private water-wells facilitating the scattered concentration of houses where there is an aquifer from water is pumped (Burchfield et al. 2006).

\section{Socioeconomic determinants}

Urban sprawl is also associated with the political implications derived from suburban ideals about freedom and private property (Vicenzotti and Qviström 2018). This is also inextricably linked with mobility and economic security, as well as the image of a 'good living' defined by detached or semi-detached homes with private gardens in a rural or suburban living environment (Bontje 2004). Correspondingly, Carrion and Irwin (2004) associate urban sprawl with individuals' decisions even as commercial and industrial developments at fringe-belt areas become clustered, whereas residential developments become fragmented and dispersed. This dispersion is partly encouraged by perceived urban ills-such as crime or low school quality - and discretionary decision-making (Carrion and Irwin 2004). Similarly, there is a correlation between perceived rates of crime and land affordability. This, in turn, encourage preferences on suburban areas (Qian and Wong 2012). According to empirical research, sociodemographic, economic, political and cultural forces define the primary causes of urban sprawl. These include population growth, transportation, industrialisation and economic development, rapid urbanisation, land-use 
changes of agricultural lands, migration, income growth, and flexible planning restrictions (Rosni and Noor 2016).

An extensive study carried out in Switzerland at municipal level found that determinants of urban sprawl are linked to prices of agricultural lands, value of land for construction, population growth, land accessibility, federal tax, changes in employment growth, number of homeowners, income, and commuting rates by private and public transport. The study concluded that 'the highest contribution to urban sprawl is to be expected in highly accessible areas that are not yet fully urbanised' (Weilenmann et al. 2017, p. 481). Accessibility clearly leads 'to an increased density along a rural-urban gradient which basically follows the level of accessibility' (ibid: 481) and uncoordinated planning decisions (Phelps 2012).

\section{Policy-based determinants}

Empirical studies conducted in Lagos, Nigeria, identified spatial policies as the main determinants of urban sprawl, influencing the characteristics of neighbourhoods, proximity to water bodies, and economic growth. These results indicate that institutional factors such as the skewed distribution of private land, the high costs of undeveloped land, and flexible regulations also influence sprawling growth alongside accessibility as well as land-use change of forests and farmlands (Braimoh and Onishi 2007).

In a similar vein, $\mathrm{Li}$ and $\mathrm{Li}$ (2019) found that arrangements for land-use conversion, enhancement of industrialisation and population controls stimulate urban sprawl in large Chinese cities. Institutional fragmentation allows the formation of coalitions between local government and enterprises, thus driving GDP growth and urban sprawl ( $\mathrm{Li}$ and $\mathrm{Li} 2019$ ). Local villagers also end up getting attracted to land-use conversion as the windfall compensation is higher than farming income. Finally, planners operate as 'technical actors' who justify decisions made by local or provincial officials to prioritise outer developments (Fang and Pal 2016). Studies conducted in Central and Easter Europe indicate that urban sprawl relates to the preference of new urbanisations in unregulated areas - such as conurbation zonesas they expand the municipal boundaries and new developments indirectly leverage from closer consolidated services (Spórna 2018).

As discussed, the determinants of urban sprawl correlate to geographical restrictions but primarily social, planning and policy factors (Table 1). To an extent, these determinants denote natural or regulatory constraints that affect the nature of urban sprawl itself. In addition to the fact that some such constraints are social or regulatory constructions which can be unmade-or are natural features that could be 'improved' or 'reclaimed' to allow sustainable development-further inspection is needed given the context-dependent nature of these determinants and because the Latin American context has not been examined in a similar way. 
Table 1 General determinants of urban sprawl

\begin{tabular}{|c|c|}
\hline \multirow[t]{5}{*}{ Physical and geographical determinants } & Scale of urban expansion \\
\hline & Transport and water supply \\
\hline & Population growth \\
\hline & Physical constraints (hills, bodies of water, etc.) \\
\hline & Presence of water aquifers \\
\hline \multirow[t]{11}{*}{ Socioeconomic determinants } & Suburban ideals (affordability, detached home, tranquillity) \\
\hline & Desire of private property \\
\hline & Proximity to nature/countryside \\
\hline & Perceived urban ills (crime, low-quality schooling, others) \\
\hline & Economic growth and industrialisation \\
\hline & Income and employment growth \\
\hline & $\begin{array}{l}\text { Investments in infrastructure and motorisation (car-depend- } \\
\text { ency) }\end{array}$ \\
\hline & Rapid urbanisation \\
\hline & Foreign investments \\
\hline & Prices of agricultural lands / value of land for construction \\
\hline & Taxation on developable lands / windfall gain \\
\hline \multirow[t]{14}{*}{ Policy-based determinants } & Policies of growth control \\
\hline & Locational policies (preference for outer developments) \\
\hline & Preference for unregulated areas (e.g. conurbations) \\
\hline & Discretionary decision-making (muddling through) \\
\hline & Technocratic decision-making on political goals \\
\hline & Flexible land-restriction \\
\hline & Policies of land-use conversion \\
\hline & Institutional fragmentation \\
\hline & Asymmetrical urban-rural governance \\
\hline & Policies over rural lands \\
\hline & Accessibility to rural lands and natural assets \\
\hline & Policies on windfall compensation \\
\hline & Distribution of private lands \\
\hline & dispersion of employment \\
\hline
\end{tabular}

\section{Methodology}

\section{Context of analysis: justifying Santiago de Chile}

The analysis presented in this paper is based on urban sprawl in Santiago de Chile, focussed on the south area which is described as the most important axis for suburbanisation. The city exemplifies the patterns of urban sprawl observed in other Latin American cities characterised by sprawling growth around transport infrastructure (Inostroza et al. 2013), peripheral concentration of large social housing developments (Coq-Huelva and Asián-Chaves 2019), consolidation of peri-urban (upper class) gated communities 
(Roitman and Phelps 2011) and fragmented expansion linked to both 'auto-construction' and privatised implementation of housing and infrastructure (Monkkonen et al. 2018; Heinrichs and Nuissl 2015). As part of the Latin American context, Santiago is a good example of the significance of normative planning and sociopolitical acceptance of extended suburbanisation (De Mattos et al. 2014). This case is used to identify the determinants of urban sprawl, and as a case study for abstraction and generalisation of conclusion around the main topic of this paper (Flyvbjerg 2006; Burawoy 1991). The capital city of Santiago has been subject of aggressive housing policies over the last 40 years with important consequences for social and spatial segregation (Borsdorf et al. 2007). This city reflects planning rationales adjusted to facilitate urban growth, land privatisation, and centralisation of social housing supply, all elements of a neoliberal planning approach (Vergara and Boano 2020).

Santiago mainly describes a monocentric city-model with at least four stages of urban development: (a) the historical city, (b) the consolidated city, (c) the suburban and (d) the exurban. The suburban and the exurban comprise the sprawling geography of Santiago, characterised by a wide spectrum of interstitial spaces, large-scale housing developments and a few peripheral centralities-including high-streets, warehouses, shopping centres and civic centres-that entails an emerging polycentric structure (Truffello and Hidalgo 2015). This sprawling geography is clearly delimitated by the Americo Vespucio ring road which encircles the city to connect most peripheral communes and separates suburban sprawl from the consolidated and historical city (Fig. 2).

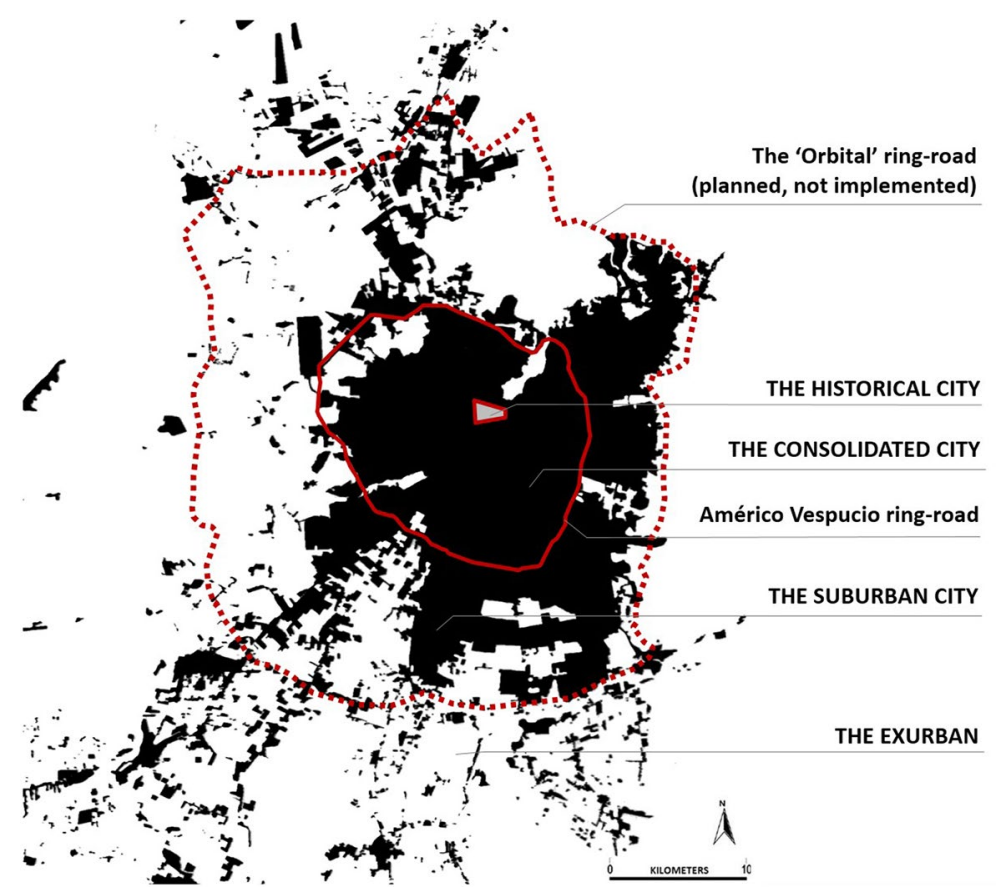

Fig. 2 Map of Santiago, its four stages of urban growth and boundaries (Author's map) 
Santiago consists of 36 communes-each one with its own local authority-with a population of 7.112.808 inhabitants representing $40.5 \%$ of the country's population (INE 2017). The analysed area comprises thirteen communes characterised by the location of large social housing developments over the last 40 years (Tapia 2011). In total, the analysed communes sum a population of 2.665.039 inhabitants, representing $37.47 \%$ of the total population of Santiago. In terms of social housing developments, Santiago records a total of 222.024 units between 1979 and 2002, in which the analysed communes concentrate a total of 159.680 units that accounts for $71.92 \%$ of the overall metropolitan stock (Fig. 3). Despite the expansion of the urban area, only $1.87 \%$ of the city's population lives in a functionally self-sufficient neighbourhoods mainly concentrated in the city centre (Correa-Parra et al. 2020).
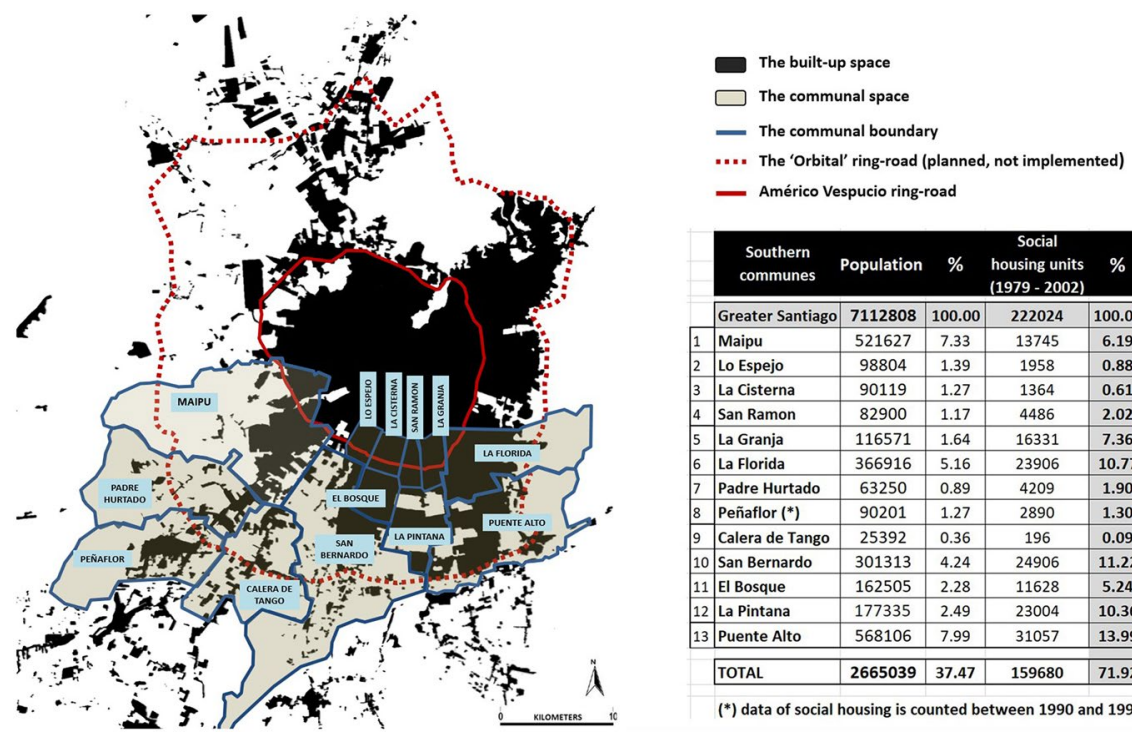

\begin{tabular}{|c|c|c|c|c|c|}
\hline & $\begin{array}{l}\text { Southern } \\
\text { communes }\end{array}$ & Population & $\%$ & $\begin{array}{c}\text { Social } \\
\text { housing units } \\
\text { (1979 - 2002) }\end{array}$ & $\%$ \\
\hline & Greater Santiago & 7112808 & 100.00 & 222024 & 100.00 \\
\hline 1 & Maipu & 521627 & 7.33 & 13745 & 6.19 \\
\hline 2 & Lo Espejo & 98804 & 1.39 & 1958 & 0.88 \\
\hline 3 & La Cisterna & 90119 & 1.27 & 1364 & 0.61 \\
\hline 4 & San Ramon & 82900 & 1.17 & 4486 & 2.02 \\
\hline 5 & La Granja & 116571 & 1.64 & 16331 & 7.36 \\
\hline 6 & La Florida & 366916 & 5.16 & 23906 & 10.77 \\
\hline 7 & Padre Hurtado & 63250 & 0.89 & 4209 & 1.90 \\
\hline 8 & Peñaflor (*) & 90201 & 1.27 & 2890 & 1.30 \\
\hline 9 & Calera de Tango & 25392 & 0.36 & 196 & 0.09 \\
\hline 10 & San Bernardo & 301313 & 4.24 & 24906 & 11.22 \\
\hline 11 & El Bosque & 162505 & 2.28 & 11628 & 5.24 \\
\hline 12 & La Pintana & 177335 & 2.49 & 23004 & 10.36 \\
\hline 13 & Puente Alto & 568106 & 7.99 & 31057 & 13.99 \\
\hline & TOTAL & 2665039 & 37.47 & 159680 & 71.92 \\
\hline
\end{tabular}

(*) data of social housing is counted between 1990 and 1998

Fig. 3 Map of Santiago, the southern communes and their population and social housing units (Author's map based on INE 2017; Tapia 2011; Hidalgo 2007 and Fernandez 2008) 


\section{Research design, methodological approach and methods}

The findings of this paper are the outcome of a study-case research conducted between 2012 and 2017, in which a mixed methodological approach was used to articulate qualitative and quantitative data (Tashakkori and Creswell 2007). The methods included documents review, site visits, morphological analysis and mapping, as well as analysis of semi-structured interviews with relevant actors. The analytical approach is based on the examination of policy conflicts and stakeholders' understandings of Santiago's urban development, which made it possible to ascertain how planning policies give effect to suburban sprawl in Santiago.

Document review (Bowen 2009) implied secondary research and institutional policies, legal norms, central development plans and regulations, urban design projects, municipal development plans, and historical records covering Santiago's urban growth. Thematic analysis and critical review of these documents allowed for the identification of key themes around the different determinants of urban sprawl (Gavin 2008). This information was collated with empirical data from official statistical databases (INE 2017) and information provided by 56 semi-structured interviews - conducted between 2014 and 2016-with a range of actors selected by their first-hand knowledge of Santiago's urban development (Stender 2017; Galletta 2013). Interviewees were carried out with planners and designers of large urban projects in Santiago, policy-makers and politicians (central/local), metropolitan authorities, social and environmental organisations, residents, academics, as well as private developers. These interviews were designed in accordance with the sponsors' ethical codes of conduct; key informants were anonymised, so that the respondents could be candid, without any fear of social, professional or political repercussions. Thematic analysis was implied to codify data into four categories: (a) Policy-based determinants, (b) Economic determinants, (c) Infrastructural (and physical) determinants and (d) conceptual (hermeneutic) determinants, all linked to contents of policy documents (Evans and Lewis 2018).

Site visits and direct observations were conducted between 2014 and 2016 to assess the spatial quality and ongoing suburbanisations. These observations were based on Rayback's approach (2016), who suggests visual records (photographs) and measurements to establish commonalities and differences, and corroborate whether an area of analysis meets the study goals (Rayback 2016). Photographs provided technical accuracy, flexibility of perspectives, and mobility to obtain specific views of the area of analysis. These are deemed evidence-specifically on physical infrastructure, environmental and spatial attributes, land-uses, day-to-day activities, accessibility, and quality of surroundings - to contrast maps and written records (Collier and Collier 1986), and provide data on the morphological and material composition of Santiago's suburban sprawl (Roberts 2016). Morphological analysis included mapping the suburban expansion of Santiago over the last 40 years following a Conzenian approach where building patterns, open space, land subdivisions, streets, vegetation, and land land-uses were documented (Kropf 2011). 


\section{Determinants of Santiago's urban sprawl}

Santiago de Chile shares common patterns of urban development with most Latin American cities (Flores et al. 2017; Herzog 2015; Rojas, et al. 2013). In Chile, this urban development has been invoked as 'urban dispersion' (Heinrichs et al. 2009), 'urban fragmentation' (Link 2008), 'metropolitan expansion' (De Mattos 1999), ‘extended suburbanisation' (De Mattos 2001) and 'dispersed urban expansion' (Ducci and Gonzalez 2006). Morphological studies on the peri-urban areas, however, have confirmed this development as urban sprawl (Rojas et al. 2013). Specifically, the development has been elucidated as a fragmented space characterised by the presence of varied neighbourhoods, interstices, and a sustained expansion to outer zones (Gainza and Livert 2013).

Santiago's sprawl has been debated since the 1980s after the enactment of The National Policy of Urban Development (NPUD/1979), which declared that urban land was a non-scarce resource and abolished the 'urban limit', 'allowing urban sprawl and doubling the metropolitan area of cities, such as Santiago' (Vergara and Boano 2020, p. 6). The underlying politics behind the NPUD related to a radical shift from previous centre-left/socialist regimes-in which access to land was considered a right - towards a neoliberal approach whereby land was commodified and managed under market-driven dynamics (Barton et al. 2012). A first amendment to the NPUD/1979 was issued in 1985. However, it did not change the essential features of the 1979 policy apart from giving more relevance to the state to foster urban development through a subsidiary approach (Gross 1991). Following the 2010 earthquake, Chile's president Sebastian Piñera ordered the conformation of a technical board to elaborate a new Urban Development Policy. A new version of this policy was published in 2014 by the Ministry of Housing and Urbanisation (MINVU 2014c), with clear statements about promoting a sustainable urban development. However, the policy does not strongly place 'urban sprawl' as an issue. Instead, it focuses on determining how the impacts of the urban expansion can be absorbed via compensation and promotion of inner densification. In Sect. 2 (economic development), objective 2.3, point 2.3.5., the policy states:

To establish a framework of special obligations to new areas of urban expansion, in order to ensure their responsibility on the externalities. Also, to establish a framework of incentives to densification projects to address the impacts over the public space and urban functions in accordance to the law (MINVU 2014c, p. 35).

In the NPUD/2014, a clear assumption is made that inner densification contributes to sustainable development. This is acknowledged by highlighting some census data around increments in the housing stock over the past 20 years, a higher construction rate of apartments in comparison to detached houses, and a reduction in the rate of expansion in major cities. Apart from minor changes, the sprawling pattern has been a longstanding trend with permanent impacts at environmental, economic, and social levels (Romero and Órdenes 2004). There is also a correlation between sprawling growth and environmental, residential, and sociospatial segregation 
(Romero et al. 2012; Sabatini et al. 2009). The latter is recognised by NPUD/2014 as a major challenge "caused by decades of advances in reducing the housing shortage from a quantitative approach, without paying attention to the location of housing and access to basic public goods' (MINVU 2014c, p. 9). However, this policy has come under strong criticism due to its lack of conceptual accuracy around the notion of 'segregation' and its practical implications in planning. Besides overlooking critical problems of land-management, land-market, and land policy (Sabatini 2015), it lacks concrete mechanisms to control capital gain (and windfall gain) resulting from uncontrolled urban growth (Trivelli 2015). Finally, the NPUD/2014 lacks the legal status as the 'General Ordinance of Urbanism and Constructions' (MINVU 2014b) regulates the public and private operations on the urban space, and must first be changed to ensure the NPUD/2014 possesses appropriate power to leverage urban development.

In this policy context, unpacking the determinants of Santiago's suburban sprawl becomes relevant, as sprawling growth appears as a less controlled process in planning (Cortés and Iturra 2019). In this paper, at least thirteen determinants are identified and sorted by policy-based, economic, infrastructural, and conceptual determinants.

\section{Policy-based (and regulatory) determinants}

A first range of determinants relates to the Chilean constitutional arrangementdefined at the end of the 1970s (Inzulza and Gatica 2019)_-in which a set of legal norms frames the planning system. These norms enforce the state to be prescriptive about planning and delimitating the role of planners as 'administrative technicians'-professionals who approve or reject planning applications on the basis of these norms. The evaluation of projects in their own merits (or in a case-by-case basis) and in light of 'the public interest' - which is the essential divide with the British planning practice (Cirianni et al. 2013) — have an intricate legal framework that is highly debated regarding the standards for implementing projects that effectively contribute to the public interest. Legal norms aim to consolidate common standards, legal certainty, and fair assessment while being efficient in the use of scarce resources. Additionally, these norms shape the planning system as a 'regulator' of private initiatives, leaving the role of the state as subsidiary of low-income families.

\section{Planning policies, regulations, and social housing developments}

Low-income groups and maximisation of public benefits defined the supply of lowcost housing in cheaper lands beyond urban boundaries, thus allowing families to become 'landowners' and beneficiaries of public benefits (Valdivia et al. 2012). The financial scheme was a 'subsidy to the house' to complement families' savings, which has had a recognised quantitative significance in reducing the housing shortage. However, the massive delivery of subsidies defined a huge concentration of poverty highly dependent on public transport (Hidalgo 2019). This policy was 
reinforced by implementing repetitive housing typologies, including the 'caseta sanitaria' (sanitary hut) composed of a basic toilet and installations for mounting a kitchen; over time, families would gradually build the rest. Urban services were not implemented, resulting in a vast concentration of clusters of basic shelters. Housing extensions were informally done and after a few years, the resulting suburbia was a patchwork of roads, farming areas, and semi-informal neighbourhoods concentrated in the southern peripheries of La Pintana, San Bernardo, Puente Alto, Padre Hurtado, Maipu, and El Bosque. The situation of La Pintana is described as follows:

The area "El Castillo" originally had about 25,000 poor residents. The overcrowding was horrible, and crime exponentially grew. Current social houses are about $30 \mathrm{~m} 2$ with a $110 \mathrm{~m} 2$ site, but these "sanitary huts" were only $2.5 \mathrm{~m} 2$ of basic services and the rest was informally finished by the families. So, people built everything wrong and with wrong materials. In many cases those small houses had up to 12 people! and without common spaces. It triggered an endless chain of problems including domestic violence, crime and others that now we all need to deal with (interview with a member of the Agricultural Cooperative José Maza, La Pintana, June 2014).

The centralised nature of planning also contributes to Santiago's sprawl as central authorities decide the place for new social housing developments. These are often in peripheral areas immediately after communal boundaries. Thus, local plans are continuously updated to incorporate new urbanisations driven by the MINVU. The creation of future housing areas distinguishes between zones of 'extension' (continuous growth) and zones of 'expansion' (discontinuous growth) (MINVU 1998), where the latter are peri-urban (or rural) communes that act as 'receivers' of new housing developments. The cases of Lampa, Buin, Maria Pinto, or Melipilla have been included into metropolitan plans since 1997. Local authorities 'consider these operations unfair; short-term centralised decisions that transfer saturation of infrastructure to local authorities' (interview with local planner at Municipality of Lo Espejo, May 2014).

Peripheral municipalities tend to reject this concentration of poverty, which is attributed to political tensions around central-local political alignment: 'this is problematic when central authorities have an average of 8000 families per year with approved subsidies but without available land' (interview with local planner at Municipality of La Pintana, May 2014). This tension is perceived as critical when compared with technical instruments, thereby 'confirming that Santiago's sprawling management is more a political exercise rather than a technical practice' (interview with senator for 8th zone of East Santiago, May 2014). These decisions imply a reduction of rural assets, the inorganic expansion of communal boundaries, concentration of peripheral poverty, and saturation of local services, all of which are elements of sprawling growth.

\section{Regulatory weaknesses}

Santiago's urban sprawl also relates to various regulatory weaknesses which allows for uncontrolled growth to occur. Real estate firms command their projects through 
these weaknesses to implement larger housing developments and maximise profitability. As an example, for social housing, the regulation requires an additional study of transport impact for projects of 250 car-parking lots or more (MINVU 2003), which means extra investments in roads capacity. Therefore, developers submit (adjacent) projects of '249' parking lots to avoid this obligation:

One of the consequences of extending the city trough this exercise is that neighbourhoods end up with narrow streets and lack of parking space. So, onstreet parking becomes the norm...cars block the access to ambulances, rubbish collection, police, fire engines, etc. Large residential areas have been created in the peripheries through these 249-car-parking projects and we cannot reject them because "they are legal". This is why in Chile we say that "made the law, so, made the trick" (interview with local planner at Municipality of Cerrillos, May 2014).

Despite being 'legal', these operations extend the city through the implementation of low-density neighbourhoods with no proper transport infrastructure and end up in segregated areas that amplify the sprawling character of suburban communes.

\section{The law 3516/1980}

At the end of the 1980s and supported by the law No3.516 (1980), upper-class families started to move to peri-urban zones stimulated by the creation of the 'Parcelas de Agrado' [Plots of Pleasure]. This regulation allows residential urbanisations beyond the urban limit in $5000 \mathrm{~m}^{2}$ sites. Although a half-hectare plot will not constitute a land for agricultural exploitation, it would preserve the rural landscape despite its residential functions (Ministry of Agriculture 1980). Generally, the resulting landscape is a cluster of half-hectare neighbourhoods characterised by detached single-family houses placed in rural settings, equipped with urban infrastructure (pipes, sewage, electricity, water supply, and collection of domestic rubbish), and connected to the city by roads. Generally, there is no public transport, which means an intensified used of private cars.

To develop a 'Parcela de Agrado', developers must obtain a favourable report from the Ministry of Agriculture (one of the few powers of agricultural authorities) confirming the absence of negative impacts, residential land-uses, and land size. These are the few restrictions in comparison to traditional inner suburbia, which label 'Parcelas de Agrado' as 'free of restriction zones' (Borsdorf and Hidalgo 2005). These peripheral zones are an ambiguous scenario of governance as the (sub) urbanisation process occurs on rural lands in possession of the Ministry of Agriculture. However, extra regulation cannot be exerted as it becomes 'residential' and thus, part of the MINVU realm. Exceptional circumstances for further plot subdivisions of less than $5000 \mathrm{~m}^{2}$ can only be suggested by the Ministerial Regional Secretary of Agriculture (SEREMI) intended for social housing:

This process relies almost entirely on the SEREMIs, and it is discretionary to each regional authority during a presidential period. This is a very attractive 
position as it serves as a resort of political progression. Thus, new urbanisations - both 'Parcelas de Agrado' and social housing — tend to be approved and extend the city with almost no regulation (interview with Professional Advisor at SEREMI of Agriculture 2010-2014, May 2014).

The 'Parcelas de Agrado' is spreading around the metropolitan region, configuring a 'pseudo-(sub)urbanisation'-identified as 'the infiltrated city' (Naranjo 2009)—that has significantly reduced proper farming lands and blurred the urban-rural transect that has even encompassed mall outer towns (Boccardo 2011).

\section{The relocation of slums}

One longstanding determinant of Santiago's sprawl relates to the eradication of slums from central areas. This process has been operational since the 1980s, when the city witnessed the highest rate of informal occupations (Swatson 1998). These occupations were then eradicated to southern communes; an operation with a double purpose: providing houses to low-income families and liberating central areas for profitable real estate projects. During the 1990 s, this policy was intensified to transform landownership while justifying the implementation of social programmes:

Poor people were moved here to have a house, then they wanted to go to their workplaces at the city centre. The only connection was the Santa Rosa Avenue, and was not enough. So, many gardeners, carpenters, builders, nannies and others from La Pintana lost their jobs because it takes so long to arrive on time. These plans of eradication with poor urban standards extended the city and left these people behind...all for the sake of becoming a 'landowner' (interview with local planner, Municipality of La Pintana, May 2014).

The overall outcome is a dispersed expansion of the city through the concentration of poverty in the southern peripheries. This increased the spatial segregation that transformed Santiago into one of the most segregated cities in Latin America (Sabatini et al. 2009).

\section{The 'urban limit'}

This containment policy was implemented in 1960 through the 'Intercommunal Regulator Plan' (PRI). The purpose was to set the city's boundary and restrict urbanisations beyond the specified limit. However, the urban limit has been constantly modified to incorporate new developments since the 60s. For some, the 'urban limit' is a disturbing tool as the division of a land in 'urban' and 'rural' by an arbitrary line increases its value without any condition or extra-cost for the owner (windfall gain). Additionally, land subdivision encourages landlords to alter functions of those portions outside the limit since their profitability increases with real estate projects. Therefore, the 'urban limit' has a paradoxical effect: while it attempts to prevent uncontrolled growth and protect agricultural lands, it also creates a perverse incentive for incorporating the countryside in trying to modify norms and functions 
(López 1981). As an undesirable side-effect, low-income families must be relocated further away on cheaper lands.

Detractors of the 'urban limit' consider its abolition as panacea for rectifying land-market distortions, increasing the land stock, and simultaneously decreasing land prices. Accordingly, the 'urban limit' was abolished in 1979 to allow development in any location within the regional space (Fig. 4). However, landlords did not sell their lands and kept them undeveloped to catch value over time. Santiago's peri-urban space entered into an unprecedented land-banking exercise that created rings of unaffordable lands around the city. Thus, low-income families were located in remote rural areas without proportionated responses in transportation, employment, and services (Rodríguez y Sugranyes 2004). In this process, Santiago's fringes became fragmented and shaped by low-quality neighbourhoods interspersed with expensive rural lands. In 1994, this 'urban limit' was finally reinstated (PRMS/1994), including zoning for future housing developments (MINVU 1998).

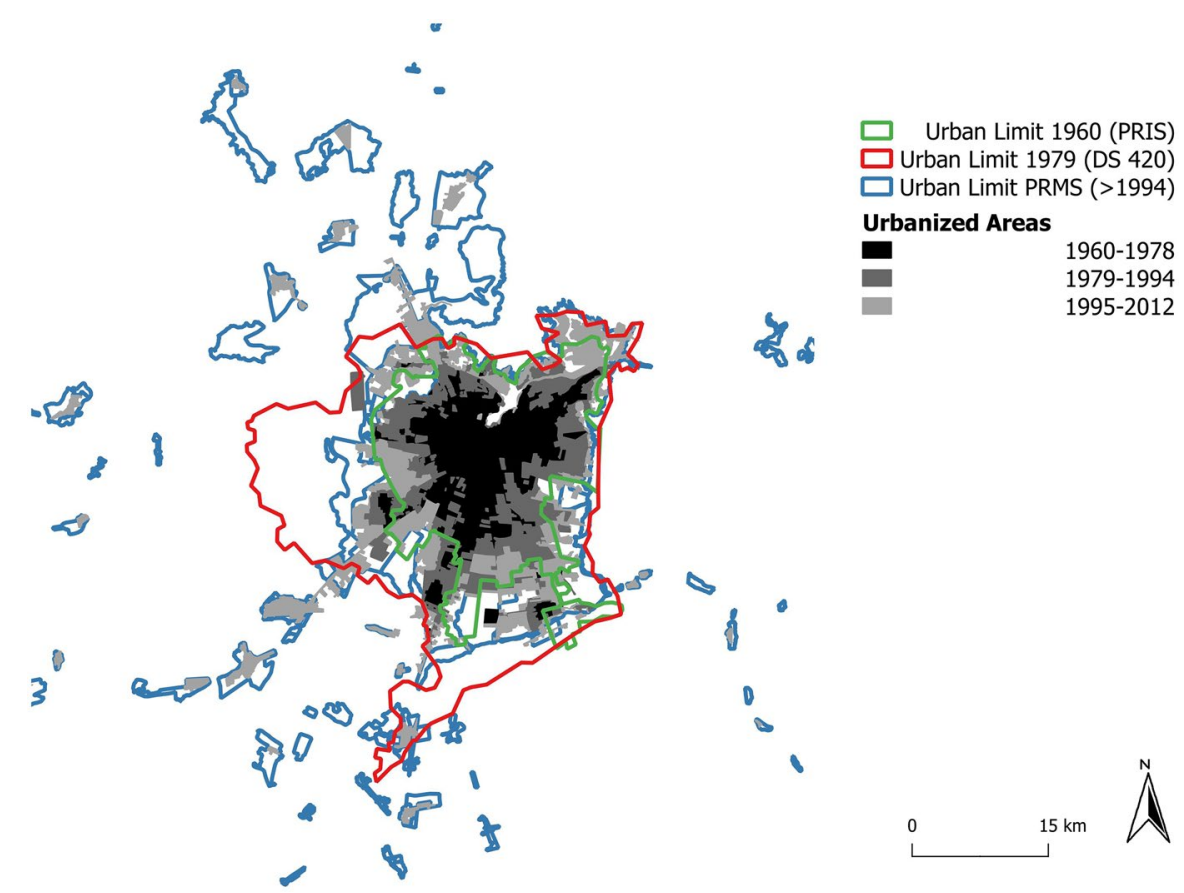

Fig. 4 Evolution of Santiago's expansion and the urban limit (authors' map based on data from Observatorio de Ciudades UC) 
The implementation of urban limits in Santiago - as not being supported by controls on the land-market-contributed to encroachments of adjacent rural lands. Conversely, its absence created market distortions that encouraged leapfrogged development, thereby enhancing sprawling growth.

\section{Institutional asymmetries}

Rural policies have a very limited influence in controlling the encroachment of rural land by the urban expansion. In addition, agricultural authorities are often politically corseted by the views of experts and the public:

Rural authorities are in a political position in which rejecting urbanisations is unpopular among real estate firms. Additionally, mass media always shows that land and housing prices are increasing because there is a scarcity of land within the city (interview with Professional Advisor at the SEREMI of Agriculture 2010-2014, May 2014).

For agricultural authorities, cross-sectorial coordination becomes crucial in negotiating irreversible impacts of urbanisation: 'This is a challenging process that mainly relies on the leadership capacities of public authorities and agreements among political coalitions, which confirms the political dimension of the Chilean planning system' (Interview with the Director of the INIA, Ministry of Agriculture, May 2104). It is noteworthy that the asymmetric relationship between urban and rural authorities correlates to the unidirectional implementation of housing projects on rural lands, causing the reduction of rural assets and contributing to the sprawling extension of the city.

\section{Planned outer developments}

Santiago' sprawl is also increased by the creation of planned zones for urbanisation beyond the urban limits. The 'Conditioned Urban Development Zones' (ZODUCs), 'Conditioned Urban Development Projects' (PDUCs) and 'Prioritised Areas of Urban Development' (AUDPs) are examples of large-scale urban developments. Introduced by the Metropolitan Plan of 1997, these zones comprehend 300 hectares for residential purposes mainly (MINVU 2014a). In the northern metropolitan space, the implementations of ZODUCs have transformed the historic rural landscape into a constellation of upper-class residential clusters with unambiguous signs of gentrification (Inzulza and Galleguillos 2014). These developments are identified as planned 'gated communities', around high-quality private roads that connect the zones with the business districts of Lo Barnechea and Vitacura (Salazar 2010). Various real estate firms initially bought the lands and obtained approval for urbanisation in the communes of Colina and Chicureo in the north, and Pudahuel in the west inter alia (Fig. 5). 


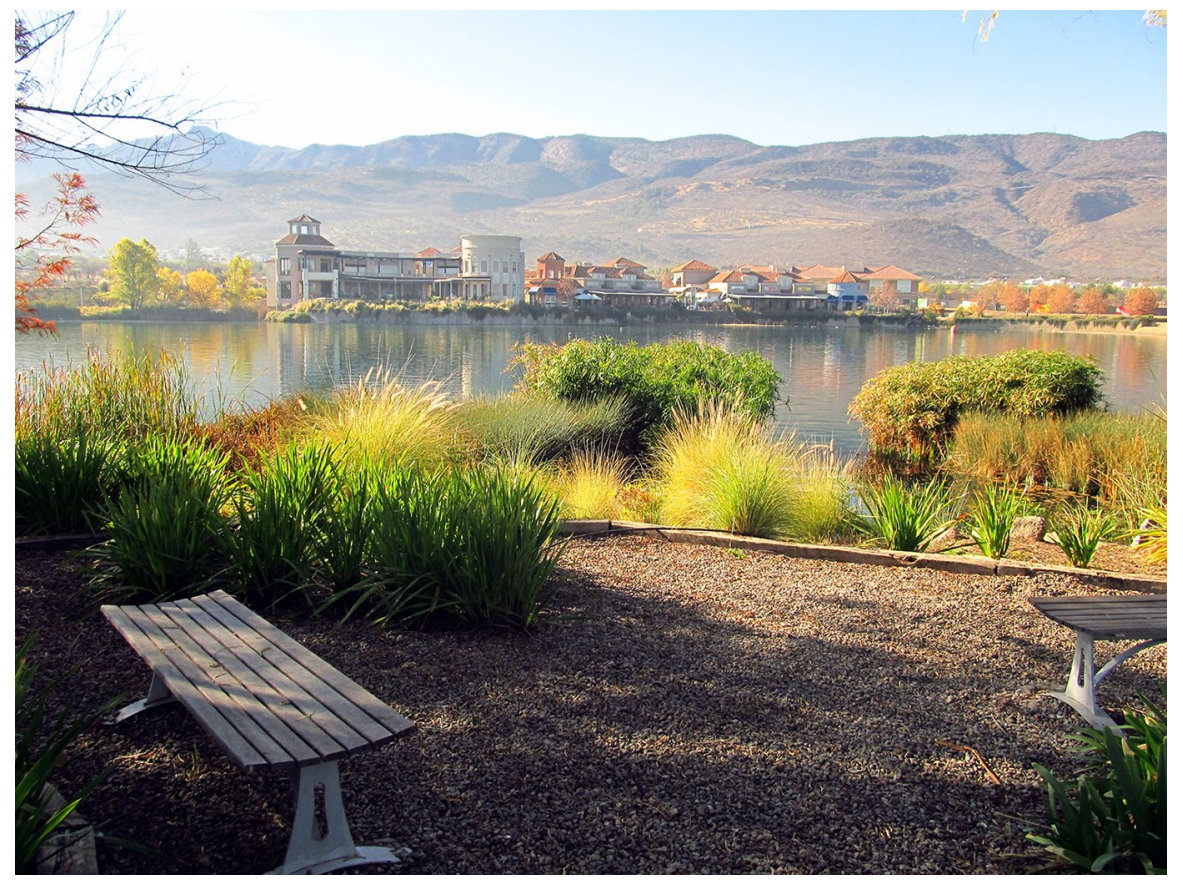

Fig. 5 A view of a private-public space, an artificial lagoon, a shopping centre and houses at the Piedra Roja private residential complex, Colina (author's photo 2014)

These zones were pioneered in incorporating externalities associated to transport infrastructure (Heinrichs et al. 2009), as private developers were required to provide motorways, commercial services, light industry, public space, water plants, security and others, and configure a privatised suburban space with high levels of functional self-sufficiency. Arguably, 'these new settlements have begun to acquire government functions and civic spaces along with greater density and mix use of developments and buildings' (Phelps 2015, p. 32). In one way or another, the ZODUCs have become a Latin American version of suburban 'minicities' (Røe and Saglie 2011). Their impacts are linked to leapfrogged development and a type of suburbia with clear signs of spatial segregation at metropolitan levels (Cooper and Henríquez 2010).

\section{Economic determinants}

For central authorities, Santiago's sprawl relates to the costs of enabling inner lands for housing due to the land price and lack of mechanisms to internalise capital gain. Land-value capture from public investments do not have the proper legal basis to levy, which provides an advantage to private sectors. Similarly, local authorities change their development plans to enable lands for development (of further densification), which is a plus value also captured by the private sector. This translates into 
a restriction to the public budget with consequences on regressive investment on inner lands or the implementation of a robust urban regeneration policy (Sepúlveda and Larenas 2011).

\section{The absence of urban regeneration policies}

The absence of an urban regeneration policy stimulates the search of peripheral lands for urbanisation. Despite efforts of retrofitting - such as the programmes 'Zonas de Renovación Urbana' (Zones of Urban Renewal) and 'Quiero mi Barrio' (I Love my Neighbourhood) — a standard policy to recover obsolete industrial lands, underused areas, infrastructural zones or any type interstitial space has not been fully implemented (Páramo and López 2020). In 2012, a study of the Chilean Chamber of Construction (C.Ch.C.) detected numerous vacant plots of more than two hectares without restrictions for densities of around 150 people/hectare (higher than Santiago's average of 85 people/hectare) that are irrecoverable. In 1992, a state-led regeneration programme was implemented only for central areas (Zones of Urban Renewal) to stimulate re-densification via subsidising first-time buyers (Verdugo 2003). However, this programme was not extended to other districts, intensifying the search of peripheral lands to respond to housing shortages.

For developers, an additional problem relates to the historical 'atomisation of the land' - the continuous subdivision of land in smaller properties - that impedes the reconversion of large areas:

It is easier to transform an urban area when the land is not too "atomised". This is the outcome of transforming everyone in a landowner. So, when we want to develop a project, we find the area transformed into a cluster of smallscale landlords and we must negotiate with all of them! ... simply impossible. So? Better to find peripheral larger plots (interview with Honorary Advisor and real estate developer, Chilean Chamber of Construction, May 2014).

An over-protection of historical low-density neighbourhoods linked to conceptual understandings of 'identity' and 'place attachment' is also a restriction for urban regeneration:

We have several very low-quality areas in Santiago of two/three-story houses, functionally obsolete, abandoned, without maintenance. Do these really have any historical or architectonic value? So, the absence of a regeneration policy does not allow recovering them because we do not have legal certainty and thus, peri-urban zones remain more attractive (interview with the Coordinator of Housing and Real Estate Development at Chilean Chamber of Construction, May 2014).

The absence of a regeneration policy contributes to the inorganic growth of Santiago as it indirectly stimulates the search of peripheral lands for suburbanisation. It also does not support land-mixing for having large plots as an alternative to land-atomisation. 


\section{No taxation on undeveloped lands}

For many years, the absence of any form of impact fee on private vacant landsor internalisation of capital gain-has contributed to discontinuous urbanisations, as landowners leave suburban lands undeveloped. This has indirectly influenced the location of new housing beyond consolidated urban areas. Importantly, this absence of financial restriction was a strong stimulus to land-banking:

In Chile we have a serious problem with land-banking that should be part of the tax reform. The law indicates that lands pay taxes regarding their "functions" (not location). So? landowners label their sites as "rural" to avoid taxation. This is a direct incentive from our policy, as landowners get the capital gain without paying for that. Some landowners are indeed foreign investors that see the business...they literally buy lands and keep them empty for years. Then, they sell them with no taxation at all (interview with the National Director of Urban Development, MINVU, May 2014).

In many cases, these undeveloped sites are abandoned - and as not entitled for public maintenance and security — subject to physical erosion that affects the entire suburban landscape. Over a period of time, they become socially accepted as part of the landscape (Fig. 6). An effective land taxation over 'non-agricultural' undeveloped lands has been applied by the Internal Revenue Service (SII) only since 2017. However, the absence of mechanisms of value capture for years did not contribute to inner densification. It also forced the search of peripheral lands for social housing that contribute to sprawl.

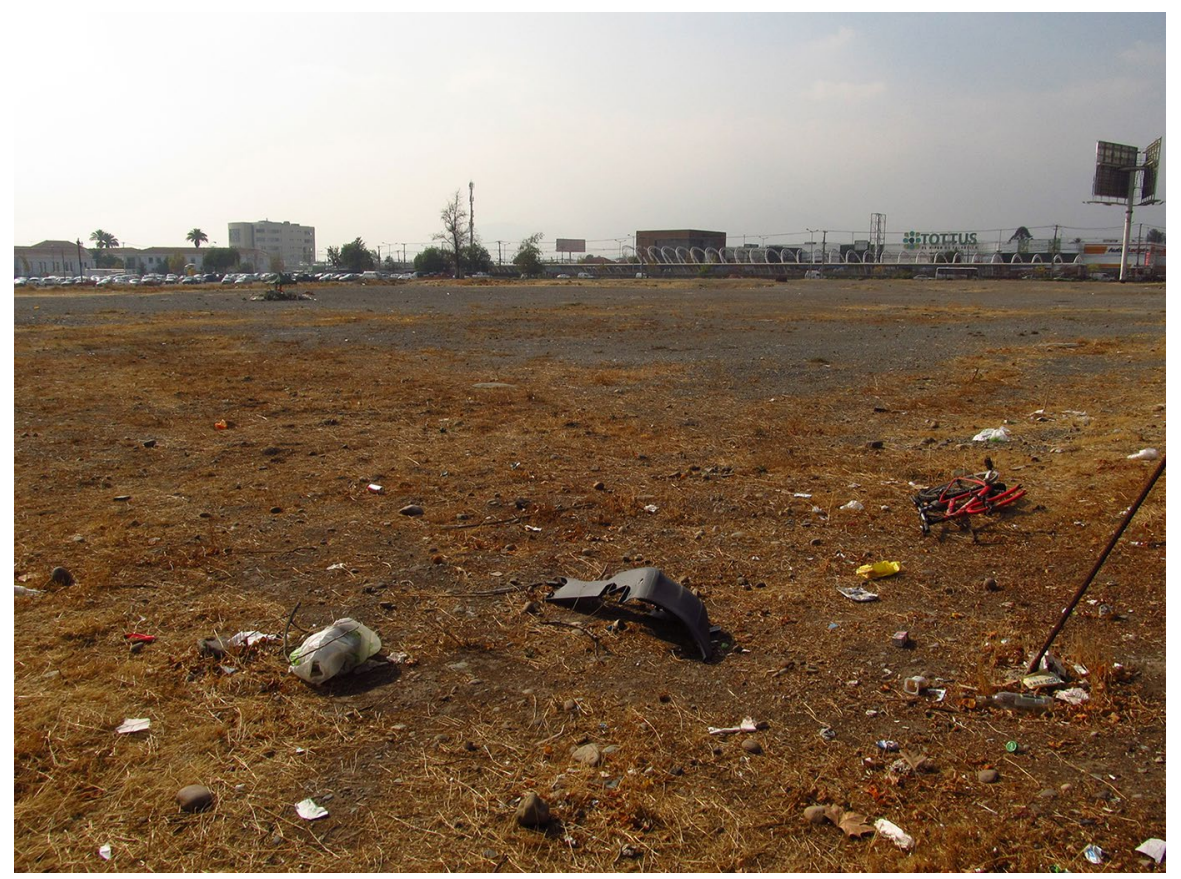

Fig. 6 An abandoned private site in La Cisterna (author's photo 2014) 


\section{Infrastructural determinants}

Some suburban municipalities are known to have land capacity to increase their density, but lack the road capacity to assimilate increments of car use and public transportation associated with densification.

\section{Improvement of roads capacity}

Local authorities must request road updating to central authorities-specifically, the Ministry of Public Works (MOP)—which requires a technical justification based on urgent needs often linked to natural disasters or regional priorities. Therefore, local authorities justify investments via development projects, pointing at the improvement of roads capacity to avoid urban sprawl. If technical capacities are limitedwhich is the case for low-income communes_road plans tend to be technically poor and therefore, rejected. In this scenario, political leadership and negotiation skills become critical and highly politically sensitive:

The state never relies solely on technical reports for the improvements of our roads. These improvements strongly depend on our political and technical teams, and our possibilities to convince different people at central levels around common goals. However, if our mayor is in the wrong side (politically speaking), we would need to wait for the next political cycle to get support and improve our road capacity. By then, the city has been further expanded (interview with local planner at Municipality of Maipu, May 2014).

If local authorities do not belong to the political coalition of the central government, the assessment of a municipal project can be delayed or rejected. This has significant implications at economic and social levels as road capacities in Chile are designed to support six-story housing blocks, restricting the implementation of high-rise buildings. A six-story building does not require lifts (MINVU, OGUC/2014), which makes the block affordable for low-income families and restricts the arrival of medium/high-income families that prefer lifts. Consequently, the area becomes unattractive for private developers and creates political tensions as local authorities are unable to achieve higher rates of social mobility. As seen, outdated roads do not allow further inner densification that enhance the search of outer rural lands for new housing developments.

\section{Regional infrastructure}

The expansion of railway services and of motorways to satellite tows and other regional services - such as port-ship areas-often triggers (unplanned) 'transitoriented development' (TOD) that consolidates conurbation processes. Led by the Ministry of Public Works (MOP), the extension of transport infrastructure creates 
opportunities for developments in the in-between lands. In other cases, the MINVU approves new urbanisations in the conurbation space without proportional responses in transport infrastructure, thus illustrating a lack of cross-sector coordination between central authorities:

It is important to define the connectivity first. If not, new neighbourhoods will have problems of congestion and accessibility. If the MOP or the real estate firm do not update the road capacity, how traffic congestion will be absorbed? and by 'who'? In our commune there is only one large road to connect the city with these new developments, but the MOP is instead updating other roads. For sure our one will collapse. The central authorities are in debt with the southern communes as they solve their regional issues but creating local problems. We are now forced to approve housing projects over this road which is not prepared for this new demand; it is still a rural road (interview with local planner as Municipality of Padre Hurtado, June 2014).

Regional connectivity influences the encroachment of rural lands as they become accessible to real estate projects, industries, and the scattered location of metropolitan facilities that contribute to urban sprawl.

\section{Conurbation zones}

As mentioned before, conurbation zones are linked to transport corridors. These areas are increasingly complex due to the unregulated coexistences of rural and urban functions inter alia. The typical landscape of Santiago's conurbations reveals a heterogeneous amalgamation of farming lands, high and low-income residential neighbourhoods, heavy and light industries, interstitial spaces, military facilities, and geographical restrictions such as rivers, lakes, and hills. In these zones, many lands keep agricultural functions and industries, including animal breeding and milk factories that coexist with residential zones (such as those framed by the Law 3516/1980). After a while, conurbations become contested spaces where industrial noise, smell, pollution, farming, and traffic of heavy vehicles collide with residential functions:

When water canals - which are open tracts - pass through a neighbourhood it is used to throw rubbish! and we cannot close them because there is a restriction to build over it. So, developers should keep them untouched. Thus, people have an open tract within their properties of at least two metres wide. In other cases, underground canals are pierced by tenants to get an 'extra pipe'! water from laundry and kitchen is melted with the water used for agricultural purposes (interview with the President of Water Community Villa Las Rosas, La Pintana, June 2014).

Amidst these tensions, the MINVU and housing developers prevail as the unintended use of chemicals and hazardous substances in agriculture impact on people's health and thus, land-use changes from rural to residential are implemented (Fig. 7). 


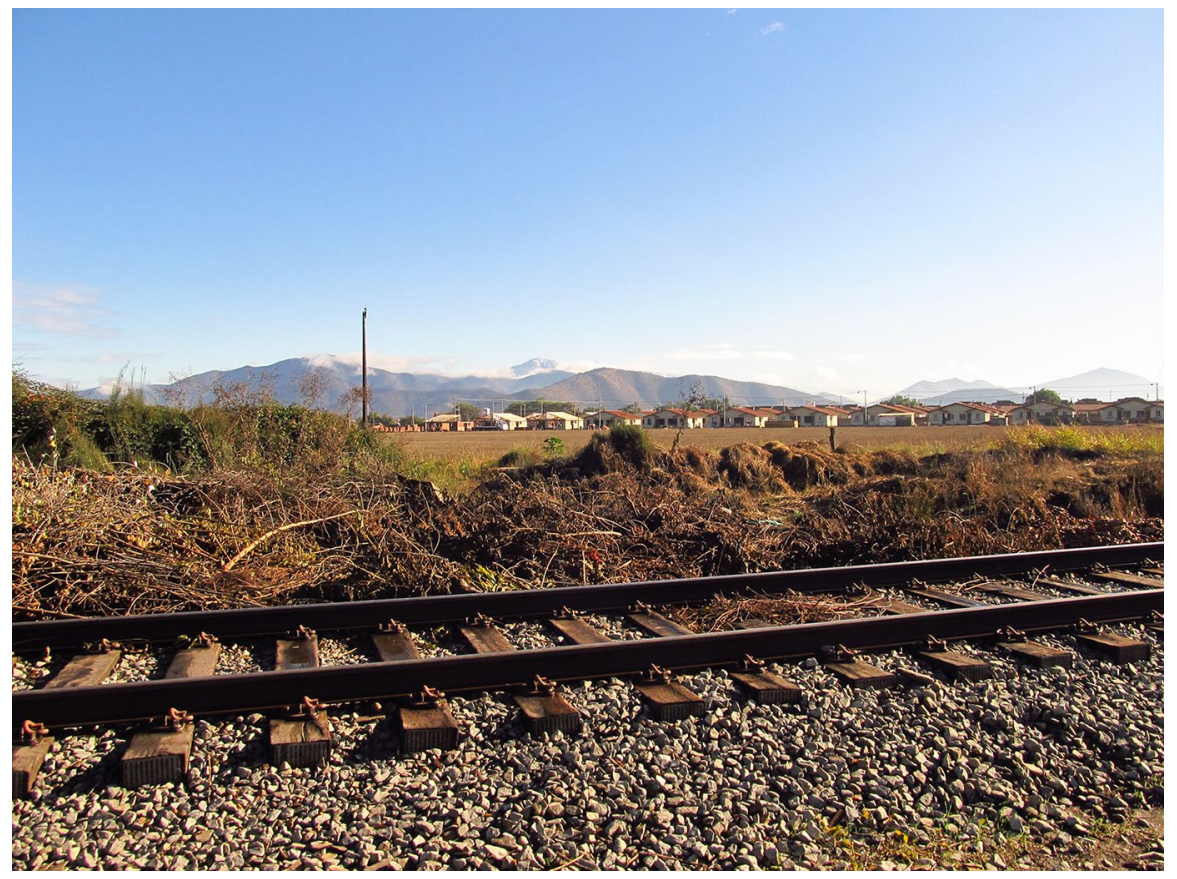

Fig. 7 Railway lines in the conurbation between Santiago and Padre Hurtado. At the back, farming spaces and new social housing developments (author's photo 2014)

Conurbation zones are unregulated spaces in which the encroachment of rural lands is linked to regional connectivity. In these zones, there is also a mixed governance whereby both rural and urban activities take place, thus contributing to the scattered growth of Santiago.

\section{Conceptual ambiguities: what is finally the problem?}

Although there is abundant literature on Santiago's metropolitan expansion (Truffello and Hidalgo 2015; De Mattos et al. 2014; Link 2008; Ducci and Gonzalez 2006; De Mattos 2001; Armijo 2000), there is no consensus among central authorities about what better describes Santiago's pattern of urban growth (Fuentes and Pezoa 2018) and what are the policy implications: 'there is an ambiguous interpretation - at the core of the central planning practice_-of what urban sprawl is. We have divergent positions-even within the same political coalition-about restraining 
or intensifying Santiago's sprawl' (interview with Director of Consultants, MOP. May 2014). While urban sprawl continues to be debated, planning solutions tend to be delayed. For some, this delay has evinced a deliberate position of 'planning for growth' since the mid-1970s; the outcome of a neoliberal agenda that has instrumentalised planning to promote further sprawl and 'has transformed urban design to make it an efficient mechanism for capital accumulation' (Vergara and Boano 2020: (1). Here, suburban sprawl has become utilitarian for the serial production of massive residential space with homogeneous aesthetics (ibid 2020) at the expense of having the environmental and social sustainability under siege (Romero and Órdenes 2004). This conceptual ambiguity contributes to urban sprawl as it restrains not only the implementation of controls over the scattered expansion, but also collaborative debates around the efficacious ways of peripheral land managing.

As discussed, a total of thirteen determinants-clustered into policy-based, economic, infrastructural and conceptual-influences Santiago's urban sprawl (Table 2).

Table 2 Determinants of Santiago's urban sprawl

\begin{tabular}{lll}
\hline Policy-based determinants & 1 & Planning and housing policies \\
2 & 3 & Normative gaps \\
& 4 & The law 3516 (1980) \\
5 & Relocation of slums \\
& 6 & The 'urban limit' \\
& 7 & Institutional asymmetries \\
Economic determinants & 8 & Planned outer developments \\
Infrastructural determinants & 9 & No taxation on undeveloped lands \\
& 10 & Improvements on roads capacity \\
Conceptual determinants & 11 & Regional transport infrastructure \\
& 12 & Conurbation zones \\
& 13 & Ambiguities around the meanings of urban sprawl- \\
& & how urban sprawl is manifested-Disparities \\
around benefits and impacts of urban sprawl-dis- & parities between growth v/s no growth
\end{tabular}




\section{Conclusions}

Despite the implementation of urban growth boundaries, urban sprawl remains an intractable predicament for spatial planning. This is partly attributed to the difficulties of planning instruments to control the determinants of urban sprawl within the policy context they are manifested. The extant literature indicates that physical restrictions, socioeconomic, and policy-based determinants influence processes of urban sprawl. The empirical analysis developed in this paper confirms these determinants and proves that policy-based decisions critically contribute to urban sprawl.

As illustrated through the case of Santiago de Chile, urban sprawl is a complex phenomenon that is not possible to be managed through growth restrictions. Thus, unpacking its determinants appears as a plausible alternative for framing a more sustainable development. The determinants of Santiago' urban sprawl are contextdependent, multiple and interlinked, specifically defined by legal norms, historical relocation of slums, institutional asymmetries, restrictive controls on urban growth, the creation of planned outer developments (ZODUCs), weaknesses in planning regulations, specific laws (3.516/1980), restrictions to inner densification, improvements in regional connectivity, as well as ambiguities around the implications of urban sprawl. All these determinants are placed at different institutional levels-and with repercussions at different spatial scales - configuring a challenging policy context that calls for the development of theories of urban politics beyond normative rationales.

Considering the ethos of development plans, the failure in controlling sprawl suggests that planning in Chile has lost sight of any meaningful notion of the collective interest—placed in the SGDs_-and how agendas of urban sustainability can be implemented though traditional (post)democratic channels. The massive production of social housing attempted under modernist state interventions and the implementation of regional/ inter-urban motorways may account for the scale of the subsequent dysfunctionalities of suburban sprawl; all contradictions in the accumulation process now having to be addressed by further rounds of state interventions-such as the new version of the NPUD/2014. This confirms planning as a political practice that has far overpassed its prescriptive ethos built upon the supremacy of technical macro-scale plans.

Further research is necessitated around the strategic articulation of the determinants of urban sprawl in contexts where 'muddling through' prevails as a mode of decision-making in land-use planning. As Lindblom (1999) has shown, planning as root or rational comprehensive planning is in itself difficult to achieve, as it rests mainly on piecemeal processes of decision-making, incremental implementation of long-term views and the assessment of urban projects in a case-by-case basis. The introduction of environmental studies is also relevant for examining the extent to which urban sprawl in Santiago contributes to $\mathrm{CO}_{2}$ emissions and other environmental issues highlighted by the SDGs - an agenda that is subscribed to by the Chilean government. It places the importance of Santiago's sprawl and its value in forcing inter-disciplinarity in urban studies. Therefore, it is necessary for a strategic approach to consider cross-sectorial coordination, alignment between local and 
central authorities, and innovations in suburban governance. Unpacking the determinants of urban sprawl offers an alternative point of entry into the studies of suburbanisation and associated dilemmas around 'grow or not to grow', also shedding light on how urban sprawl can be articulated as a distinctive geographical space that deserves planning and policy approaches in its own right.

Acknowledgements The authors would like to thank the editors of the journal and anonymous reviewers for their insightful comments on the previous versions of this article. The authors are grateful to interviewees for providing data and valuable insights for this article.

Author contributions The corresponding author contributed to the study conception and design. Material preparation, data collection and analysis were mostly performed by Cristian Silva with collaboration of Francisco Vergara-Perucich. The first draft of the manuscript was written by Cristian Alejandro Silva Lovera, and all authors commented on second and third versions of the manuscript. All authors read and approved the final manuscript.

Funding This work was supported by the National Commission of Science and Technology of Chile, CONICYT, Grant 72110038; the FONDECYT Project Number 11180569; the School of Natural and Built Environment (SNBE), Queen's University Belfast (QUB), Grant D820PAC.

Data availability The datasets of semi-structured interviews generated during and/or analysed during the current study are not publicly available due to restrictions imposed by the ethical assessment of the research (Ethic Application ID: 5588/001, 2014, University College London) that required interviews to be anonymised so that the respondents could be frank, without fear of professional repercussions. Statistical data of Santiago de Chile, Chilean population, housing stock and others from institutional sources are publicly available through the links indicated in the reference list attached to each used source.

\section{Declarations}

Conflict of interest On behalf of all authors, the corresponding author states that there is no conflict of interest.

Ethical statement The content and results presented in this paper are part of a research carried out at University College London (UCL), approval of ethics assessment granted under the application ID: 5588/001, 2014

Open Access This article is licensed under a Creative Commons Attribution 4.0 International License, which permits use, sharing, adaptation, distribution and reproduction in any medium or format, as long as you give appropriate credit to the original author(s) and the source, provide a link to the Creative Commons licence, and indicate if changes were made. The images or other third party material in this article are included in the article's Creative Commons licence, unless indicated otherwise in a credit line to the material. If material is not included in the article's Creative Commons licence and your intended use is not permitted by statutory regulation or exceeds the permitted use, you will need to obtain permission directly from the copyright holder. To view a copy of this licence, visit http://creativecommons.org/licen ses/by/4.0/.

\section{References}

Abubakar IR, Doan PL (2017) Building new capital cities in Africa: lessons for new satellite towns in developing countries. Afr Stud 76(4):546-565

Altieri L, Cocchi D, Pezzi G, Scott EM, Ventrucci M (2014) Urban sprawl scatterplots for Urban Morphological Zones data. Ecol Ind 36:315-323 
Amati M (2016) Green belts: a twentieth-century planning experiment. In: Amati M (ed) Urban green belts in the twenty-first century. Routledge, New York, pp 1-18

Armijo G (2000) La urbanización del campo metropolitano de Santiago: crisis y desaparición del hábitat rural [The urbanisation of the metropolitan countryside of Santiago: crisis and fading of the rural habitat]. Revista de Urbanismo 3:1-21

Bagheri B, Tousi SN (2018) An explanation of urban sprawl phenomenon in Shiraz Metropolitan Area (SMA). Cities 73:71-90

Barrington C, Millard A (2015) A century of sprawl in the United States. Proc Natl Acad Sci 112(27):8244-8249

Barton J, Román Á, Fløysand A (2012) Resource extraction and local justice in Chile: conflicts over the commodification of spaces and the sustainable development of places. In: Haarstad H (ed) New political spaces in Latin American natural resource governance. Palgrave Macmillan, New York, pp 107-128

Beck U, Bonss W, Lau C (2003) The theory of reflexive modernization: problematic, hypotheses and research programme. Theory Cult Soc 20(2):1-33

Boccardo D (2011) Tensions of a triple urban vocation: San Bernardo Bernardo and its absortion process from Santiago de Chile. Revista Terrtitorios En Formación 2:7-20

Boland P, Bronte J, Muir J (2017) On the waterfront: neoliberal urbanism and the politics of public benefit. Cities 61:117-127

Bontje M (2004) From suburbia to post-suburbia in the Netherlands: potentials and threats for sustainable regional development. J Housing Built Environ 19(1):25-47

Borsdorf A, Hidalgo R (2005) Los mega-diseños residenciales vallados en las periferias de las metrópolis latinoamericanas y el advenimiento de un nuevo concepto de ciudad. Alcances en base al caso de Santiago de Chile [The fenced residential mega-designs in the peripheries of the Latin-American metropolises, and the arrival of a new concept of city. The case of Santiago de Chile]. Revista Electrónica de Geografía y Ciencias Sociales, SCRIPTA NOVA, Universidad de Barcelona. 9(194). http://www.ub.edu/geocrit/sn/sn-194-03.htm

Borsdorf A, Hidalgo R, Sanchez R (2007) A new model of urban development in Latin America: the gated communities and fenced cities in the metropolitan areas of Santiago de Chile and Valparaíso. Cities 24(5):365-378

Bowen GA (2009) Document analysis as a qualitative research method. Qual Res J 9(2):27-40

Braimoh AK, Onishi T (2007) Spatial determinants of urban land use change in Lagos. Nigeria Land Use Policy 24(2):502-515

Brenner N, Elden S (2009) Henri Lefebvre on state, space, territory. Int Polit Sociol 3:353-377

Bruegmann R (2005) Sprawl: a compact history. University of Chicago Press, Chicago

Burawoy M (1991) The extended case method. Ethnography unbound. Power and resistance in the modern metropolis. University of California Press, Berkeley, pp 271-290

Burchfield M, Overman HG, Puga D, Turner MA (2006) Causes of sprawl: a portrait from space. Q J Econ 121(2):587-633

Burger M, Meijers E (2012) Form follows function? Linking morphological and functional polycentricity. Urban Studies 49(5):1127-1149

Calthorpe P, Fulton W (2001) The Regional City. Island Press, London

Carrion C, Irwin EG (2004) Determinants of residential land-use conversion and sprawl at the rural-urban fringe. Am J Agr Econ 86(4):889-904

Charmes E, Keil R (2015) The politics of post-suburban densification in Canada and France. Int J Urban Reg Res 39(3):581-602

Cirianni F, Panuccio P, Rindone C (2013) A comparison of urban planning systems between the UK and Italy: commercial development and city logistic plan. WIT Trans Built Environ 130:785-797

Cobbinah PB, Aboagye HN (2017) A Ghanaian twist to urban sprawl. Land Use Policy 61:231-241

Collier J, Collier M (1986) Visual anthropology: photography as a research method. UNM Press, Mexico

Cooper M, Henríquez C (2010) Planificación territorial y crecimiento urbano: desarticulaciones de la sostenibilidad urbano-regionales en Santiago Metropolitano [Territorial planning and urban growth: disarticulations of the urban-regional sustainability in the metropolitan Santiago] . Revista Electrónica de Geografía y Ciencias Sociales, SCRIPTA NOVA, Universidad de Barcelona. 14(331). http://www.ub.edu/geocrit/sn/sn-331/sn-331-14.htm

Coq-Huelva D, Asián-Chaves R (2019) Urban sprawl and sustainable urban policies. A review of the cases of Lima, Mexico City and Santiago de Chile. Sustainability 11(20):1-22 
Correa-Parra J, Vergara-Perucich JF, Aguirre-Nuñez C (2020) Towards a Walkable City: principal component analysis for defining sub-centralities in the Santiago Metropolitan Area. Land 9(10):1-15

Cortés Y, Iturra V (2019) Market versus public provision of local goods: an analysis of amenity capitalization within the Metropolitan Region of Santiago de Chile. Cities 89:92-104

Cox T, Hurtubia R (2020) Subdividing the sprawl: endogenous segmentation of housing submarkets in expansion areas of Santiago, Chile. Environ Plan B 29:355

De Mattos C (1999) Santiago de Chile, globalización y expansión metropolitana: lo que existía sigue existiendo [Santiago de Chile, globalisation and metropolitan expansion. What is gone and what is still here]. EURE 225(76):29-56

De Mattos C (2001) Metropolización y suburbanización [Metropolitanisation and suburbanisation]. EURE (santiago) 27(80):5-8

De Mattos C, Fuentes L, Link F (2014) Tendencias recientes del crecimiento metropolitano en Santiago de Chile. ¿Hacia una nueva geografía urbana? ['Recent metropolitan growth trends in Santiago de Chile. Towards a new urban geography?']. INVI 29:193-219

Deng FF, Huang Y (2004) Uneven land reform and urban sprawl in China: the case of Beijing. Prog Plan 61(3):211-236

Dockerill B, Sturzaker J (2019) Green belts and urban containment: the Merseyside experience. Plan Perspect 35:583-608

Ducci M, Gonzalez M (2006) Anatomía de la expansión de Santiago, 1991-2000' [Anatomy of Santiago's expansión, 1991-2000]. In: Galetovic, A. (ed), Santiago: Dónde estamos y hacia dónde vamos, [Santiago: where do we are and where do we go]. Centro de Estudios Públicos, 123-46. Santiago, Chile

Dunham-Jones E, Williamson J (2009) Retrofitting suburbia: urban design solutions for redesigning suburbs. Wiley, Chichester

Evans C, Lewis J (2018) Analysing semi-structured interviews using thematic analysis: exploring voluntary civic participation among adults. SAGE Publications Limited, London

Fang Y, Pal A (2016) Drivers of urban sprawl in urbanizing China: a political ecology analysis. Environ Urban 28(2):599-616

Fernández J (2008) Pobreza urbana y políticas habitacionales en Chile (1990-2005) ¿De la exclusión social a la integración? [Urban poverty and housing policies in Chile (1990-2005). From social exclusion to integration?]. Working paper, PUC. 99-122

Fishman R (1987) Bourgeois utopias: the rise and fall of suburbia. Basic Books, New York

Flores M, Otazo-Sánchez EM, Galeana-Pizana M, Roldán-Cruz EI, Razo-Zárate R, González-Ramírez CA, et al (2017) Urban driving forces and megacity expansion threats. Study case in the Mexico City periphery. Habitat Int 64:109-122

Flyvbjerg B (2006) Five misunderstandings about case-study research. Qual Inq 12(2):219-245

Fuentes L, Pezoa M (2018) Nuevas geografías urbanas en Santiago de Chile 1992-2012. Entre la explosión y la implosión de lo metropolitano [New urban geographies in Santiago de Chile 19922012. Between the explosion and implosion of the metropolitan]. Revista De Geografia Norte Grande 70:131-151

Gainza X, Livert F (2013) Urban form and the environmental impact of commuting in a segregated city, Santiago de Chile'. Environ Plann B Plan Des 40(3):507-522

Gallent N, Shaw D (2007) Spatial planning, area action plans and the rural-urban fringe. J Environ Plan Manage 50(5):617-638

Galletta A (2013) Mastering the semi-structured interview and beyond: From research design to analysis and publication, vol 18. NYU Press, New York

Galster G, Hanson R, Ratcliffe M, Wolman H, Coleman S, Freihage J (2001) Wrestling sprawl to the ground: defining and measuring an elusive concept. Housing Policy Debate 12(4):681-717

Gargiulo C, Russo L (2017) Cities and energy consumption: a critical review. TeMA J Land Use Mobil Environ 10(3):259-278

Garreau J (1991) Edge City: life on the new frontier, 1st edn. Doubleday, New York

Gavin H (2008) Thematic analysis. In: Understanding research methods and statistics in psychology. pp. 273-281. SAGE Publications Ltd

Gillham O (2002) What is sprawl? The limitless city. A primer on the urban sprawl debate. Island Press, Washington, DC

Gottdiener M (1977) Planned sprawl. Private public interest. Suburb Sage, London

Grimes A, Liang Y (2009) Spatial determinants of land prices: does Auckland's metropolitan urban limit have an effect? Appl Spat Anal Policy 2(1):23-45 
Gross P (1991) Santiago de Chile (1925-1990): Planificación urbana y modelos políticos [Santiago de Chile (1925-1990): Urban planning and political models]. EURE 17(52/53):27-52

Hamel P, Keil R (eds) (2015) Suburban governance: a global view. University of Toronto Press, Toronto

Hamidi S, Zandiatashbar A (2019) Does urban form matter for innovation productivity? A national multilevel study of the association between neighbourhood innovation capacity and urban sprawl. Urban Stud 56(8):1576-1594

Heinrichs D, Nuissl H (2015) Suburbanisation in Latin America: towards new authoritarian modes of governance at the urban margin. In: Hamel P, Keil R (eds) Suburban governance. A global view. University of Toronto Press, Toronto

Heinrichs D, Nuissl H, Rodriguez C (2009) Dispersión urbana y nuevos desafíos para la gobernanza (metropolitana) en América Latina: el caso de Santiago de Chile [Urban dispersion and new challenges for the metropolitan governance in Latin Anerica]. EURE 35(104):29-46

Herzog L (2015) Global suburbs. Urban Sprawl in Rio Grande to Rio de Janeiro. Routledge, London

Hess G, Daley S, Dennison B, Lubkin S, McGuinn R, Morin V, Potter K, Savage R, Shelton W, Snow C, Wrege B (2001) Just what is sprawl, anyway? Carol Plan 26(2):11-26

Hidalgo R (2007) ¿Se acabó el suelo en la gran ciudad? Las nuevas periferias metropolitanas de la vivienda social en Santiago de Chile [Is the land over in the great city? The new metropolitan peripheries of state housing in Santiago de Chile]. EURE 33(98):57-75

Hidalgo R (2019) La vivienda social en Chile y la construcción del espacio urbano en el Santiago del siglo XX [Social housing in Chile and the construction of the urban space in Santiago of the 20th century]. Santiago: Ril Editores.

Horn A, Van Eeden A (2018) Measuring sprawl in the Western Cape Province, South Africa: an urban sprawl index for comparative purposes. Reg Sci Policy Pract 10(1):15-23

Inostroza L, Baur R, Csaplovics E (2013) Urban sprawl and fragmentation in Latin America: a dynamic quantification and characterization of spatial patterns. J Environ Manage 115:87-97

Instituto Nacional de Estadisticas (INE) (2017) Censo de Poblacion y Vivienda [National Institute of Statistics, INE. Statistics of population and housing]. https://www.ine.cl/estadisticas/sociales/censosde-poblacion-y-vivienda/poblacion-y-vivienda. Accessed March 2021

Inzulza J, Galleguillos X (2014) Latino gentrificación y polarización: transformaciones socioespaciales en barrios pericentrales y periféricos de Santiago, Chile [Latino gentrification and polarisation: socio-spatial transformations in peripheral and peri-central neighbourhoods, Santiago, Chile]. Revista De Geografía Norte Grande 58:135-159

Inzulza J, Gatica P (2019) Subsidiary displacement and empty plots: dilemmas of original residents and newcomers in the reconstruction of Talca, Chile 2010-2016. Urban Stud 56(10):2040-2057

Jaret C, Ghadge RW, Reid L, Adelman R (2009) The measurement of suburban sprawl: an evaluation. City Commun 8(1):65-84

Kropf K (2011) Morphological investigations: cutting into the substance of urban form. Built Environ 37(4):393-408

Lang E (2003) Edgeless cities: exploring the elusive metropolis. Brookings Institution Press, Washington

Li G, Li F (2019) Urban sprawl in China: differences and socioeconomic drivers. Sci Total Environ 673:367-377

Li LY, Qi ZX, Xian S (2020) Decoding spatiotemporal patterns of urban land sprawl in Zhuhai, China. Appl Ecol Environ Res 18(1):913-927

Lindblom CE (1999) The science of 'muddling through.' In: Miyakawa T (ed) The science of public policy, vol III. Routledge, London

Link F (2008) From polycentricity to fragmentation in Santiago de Chile. Centro-H, Revista De La Organización Latinoamericana y Del Caribe De Centros Históricos 2(02):13-24

López M (1981) Expansión de las ciudades [The expansion of cities]. EURE 8(22):31-42

Masoumi HE, Hosseini M, Gouda AA (2018) Drivers of urban sprawl in two large Middle-eastern countries: literature on Iran and Egypt. Human Geogr 12(1):55-79

Ministerio de Agricultura (1980) Division of Lands, Properties of Agricultural Allotments. DFL $\mathrm{N}^{\circ} 3.516 / 1980$ for the division of rustic plots. Available at Biblioteca del Congreso Nacional's Archives. http://www.leychile.cl/Navegar?idNorma=7155. Accessed March 2021

Ministerio de Vivienda y Urbanismo, MINVU (1998) Memoria explicativa del Plan Regulador de Santiago. Incorporación de las comunas de Colina, Lampa y Til-Til. Santiago

Ministerio de Vivivenda y Urbanismo (MINVU) (2003) Estudios de impacto sobre el sistema de transporte urbano (EISTU). Metodologia. http://www.sectra.gob.cl/metodologias/eistu.htm. Accessed March 2021

\section{SN Social Sciences}


Ministerio de Vivienda y Urbanismo, MINVU (2014a) Texto Actualizado y Compaginado, Ordenanza Plan Regulador Metropolitano de Santiago (PRMS). http://metropolitana.minvu.cl/pag-m/docum entacion-vigente-prms/. Accessed March 2021

Ministerio de Vivienda y Urbanismo, MINVU (2014b) Ordenanza General de urbanismo y Construcciones, OGUC (2014) Ministerio de Vivienda y Urbanismo, MINVU. D.F.L N458/1975. https:// www.bcn.cl/leychile/navegar?idNorma=13560. Accessed March 2021

Ministerio de Vivienda y Urbanismo (MINVU) (2014c) Towards a new urban policy for Chile: national policy of urban development. https://cndu.gob.cl/wp-content/uploads/2014/10/L4-Politica-Nacio nal-Urbana.pdf. Accessed March 2021

Monkkonen P, Comandon A, Escamilla JAM, Guerra E (2018) Urban sprawl and the growing geographic scale of segregation in Mexico, 1990-2010. Habitat Int 73:89-95

Naranjo G (2009) El rol de la ciudad infiltrada en la reconfiguración de la periferia metropolitana de Santiago de Chile [The role of the infiltrated city in the configuration of the metropolitan periphery of Santiago de Chile]. Estudios Geográficos 70(266):205-229

Nelson A (1999) Comparing states with and without growth management analysis based on indicators with policy implications. Land Use Policy 16:121-127

Osman T, Divigalpitiya P, Arima T (2016) Driving factors of urban sprawl in Giza Governorate of Greater Cairo Metropolitan Region using AHP method. Land Use Policy 58:21-31

Oueslati W, Alvanides S, Garrod G (2015) Determinants of urban sprawl in European cities. Urban Stud 52(9):1594-1614

Páramo Lopera C, López-Morales E (2020) Principios, progresividad y factibilidades de la recuperación de" plusvalías" urbanas en el Chile actual. Revista De Geografía Norte Grande 76:121-142

Patacchini E, Zenou Y, Henderson JV, Epple D (2009) Urban sprawl in Europe. In: Brookings-Wharton Papers on Urban Affairs, pp 125-149

Pawe CK, Saikia A (2020) Decumbent development: urban sprawl in the Guwahati Metropolitan Area. India Singap J Trop Geogr 41(2):226-247

Phelps N (2012) An anatomy of sprawl. Planning and politics in Britain. Routledge, London

Phelps NA (2015) Sequel to suburbia: glimpses of America's post-suburban future. MIT Press

Phelps NA, Silva C (2017) Mind the gaps! A research agenda for urban interstices. Urban Stud 55(6):1203-1222

Phelps N, Wood A (2011) The new post-suburban politics? Urban Stud 48(12):2591-2610

Pirotte A, Madre JL (2011) Determinants of urban sprawl in France: an analysis using a hierarchical Bayes approach on panel data. Urban Stud 48(13):2865-2886

Qian H, Wong C (2012) Master planning under urban-rural integration: the case of Nanjing, China. Urban Policy Res 30(4):403-421

Rauws WS, de Roo G (2011) Exploring transitions in the peri-urban area. Plan Theory Pract 12(2):269-284

Ravetz J, Loibl W (2011) The dynamics of the peri-urban: global change and regional response. In: Piorr A, Ravetz J, Tosics I (eds) Peri-urbanisation in Europe: towards European policies to sustain urbanrural futures; synthesis report; PLUREL [sixth framework programme]. Forest and Landscape, University of Copenhagen

Rayback S (2016) Making observations and measurements in the field. In: Clifford N, Cope M, French S, Gillespie T (eds) Key methods in geography. Sage, London, pp 325-335

Roberts L (2016) Interpreting the visual. In: Clifford N, Cope M, French S, Gillespie T (eds) Key methods in geography. Sage, London

Rodríguez A, Sugranyes A (2004) El problema de vivienda de los 'con techo' [The housing problem of those 'with a roof']. EURE 30(91):53-65

Røe PG, Saglie IL (2011) Minicities in suburbia: a model for urban sustainability? Form Akademisk. https://doi.org/10.7577/formakademisk.200

Roitman S, Phelps N (2011) Do gates negate the city? Gated communities' contribution to the urbanisation of suburbia in Pilar, Argentina. Urban Stud 48(16):3487-3509

Rojas C, Muñiz I, Pino J (2013) Understanding the urban sprawl in the mid-size Latin American cities through the urban form: analysis of the Conception Metropolitan Area (Chile). J Geogr Inf Syst 5:222-234

Romero H, Órdenes F (2004) Emerging Urbanization in the Southern Andes environmental impacts of urban sprawl in Santiago de Chile on the Andes Piedmont. Mt Res Dev 24(3):197-201

Romero H, Vásquez A, Fuentes C, Salgado M, Schmidt A, Banzhaf E (2012) Assessing urban environmental segregation (UES). The case of Santiago de Chile. Ecol Ind 23:76-87 
Rosni N, Noor N (2016) Review of literature on urban sprawl: assessment of factors and causes. J Arch Plan Constr Manage 6(1):12-35

Sabatini F (2015) Hacia una politica de integracion social urbana: cinco carencias de la Politica Nacional de Desarrollo Urbano [Towards a policy of urban social integration: five drawbacks of the National Policy of Urban Development]. In: La ciudad que queremos [the city we want]. pp 63-84. Biblioteca del Congreso Nacional. Departamento de Estudios, Extension y Publicaciones

Sabatini F, Wormald G, Sierralta C, Peters PA (2009) Residential segregation in Santiago: scale-related effects and trends, 1992-2002. In: Roberts BR, Wilson RH (eds) Urban segregation and governance in the Americas. Palgrave Macmillan, New York, pp 121-143

Salazar A (2010) Transformaciones socio-territoriales en la periferia metropolitana: La ciudad periurbana, estrategias locales y gobernanza en Santiago de Chile. Revista electrónica de geografía y ciencias sociales. SCRIPTA NOVA, XIV (47). http://www.ub.edu/geocrit/sn/sn-331/sn-331-47. htm

Sepúlveda R, Larenas J (2011) Regeneración urbana. Reflexiones sobre la sustentabilidad urbana en el contexto de las estrategias de recuperación barrial en Chile y Cataluña. Cuadernos De Investigación Urbanística 68:70-82

Sharifi A, Chiba Y, Okamoto K, Yokoyama S, Murayama A (2014) Can master planning control and regulate urban growth in Vientiane, Laos? Landsc Urban Plan 131:1-13

Sieverts T (2003) Cities without cities. An interpretation of the Zwischenstadt. Spon Press, London

Silva C (2019a) Auckland's urban sprawl, policy ambiguities and the peri-urbanisation to Pukekohe. Urban Sci 3(1):1-20

Silva C (2019b) The interstitial spaces of urban sprawl: unpacking the marginal suburban geography of Santiago de Chile. In: Geraghty NHD, Massidda AL (eds) Creative spaces: urban culture and marginality in Latin America. University of London Press, London

Soule D (2006) Defining and managing sprawl. In: Soule DC (ed) Urban sprawl: a comprehensive reference guide. Greenwood Publishing Group Inc., Westport

Spórna T (2018) The suburbanisation process in a depopulation context in the Katowice conurbation. Pol Environ Socio-Econ Stud 6(1):57-72

Ståhle A (2008) Compact sprawl: exploring public open space and contradictions in urban density. Doctoral dissertation, KTH

Ståhle A, Marcus L (2008) Compact sprawl experiments. Four strategic densification scenarios for two modernist suburbs in Stockholm. In: Stahle A (eds) Compact sprawl: exploring public open space and contradictions in urban density. Published Doctoral Dissertation, KTH Architecture and the Built Environment, School of Architecture, Royal Institute of Technology, Stockholm

Stender M (2017) Towards an architectural anthropology—what architects can learn from anthropology and vice versa. Arch Theory Rev 21(1):27-43

Swatson DS (1998) De tomas de terreno a campamentos: movimiento social y político de los pobladores sin casa, durante las décadas del 60 y 70, en la periferia urbana de Santiago de Chile. Revista Invi $13(35)$

Tapia R (2011) Social housing in Santiago. Analysis of its locational behavior between 1980-2002. INVI 73(26):105-131

Tashakkori A, Creswell JW (2007) Exploring the nature of research questions in mixed methods research. J Mixed Methods Res 1(3):207-211

Trivelli P (2015) Algunas reflexiones sobre la Política Nacional de Desarrollo Urbano, la Economía Urbana y el financiamiento de las ciudades [Some reflections about the National Policy of Urban Development, the urban economy and financing of cities]. In: La ciudad que queremos [The city we want]. pp 85-108. Biblioteca del Congreso Nacional. Departamento de Estudios, Extension y Publicaciones. Chile.

Trubka R, Newman P, Bilsborough D (2010) The costs of urban sprawl: infrastructure and transportation. Environment Design Guide, 1-6

Truffello R, Hidalgo R (2015) Policentrismo en el Área Metropolitana de Santiago de Chile: reestructuración comercial, movilidad y tipificación de subcentros [Policentrism in the metropolitan area of Santiago de Chile: commercial restructuration, mobility and categorisation of subcentres]. EURE 41(122):49-73

United Nations (UN) (2017) New Urban Agenda. Habitat III. United Nations Conference on Housing and Sustainable Development. ISBN: 978-92-1-132731-1. https://habitat3.org/documents-and-archive/. Accessed March 2021 
United Nations (UN) Department of Economic and Social Affairs. Sustainable development. The 17 Goals. https://sdgs.un.org/goals. Accessed March 2021

Valdivia V, Álvarez R, Donoso K (2012) La alcaldización de la política. Los municipios en la dictadura pinochetista. Santiago, Lom Ediciones

Verdugo M (2003) Programa de repoblamiento comuna de Santiago: Un programa de gestión urbana. Urbano 6(8):53-61

Vergara F, Boano C (2020) Exploring the contradiction in the ethos of urban practitioners under neoliberalism: a case study of housing production in Chile. J Plan Educ Res 15:225

Vicenzotti V, Qviström M (2018) Zwischenstadt as a travelling concept: towards a critical discussion of mobile ideas in transnational planning discourses on urban sprawl. Eur Plan Stud 26(1):115-132

Watts M (2017) Cities spearhead climate action. Nat Clim Chang 7(8):537-538

Weilenmann B, Seidl I, Schulz T (2017) The socio-economic determinants of urban sprawl between 1980 and 2010 in Switzerland. Landsc Urban Plan 157:468-482

Whitehand JWR, Gu K (2017) Urban fringe belts: evidence from China. Environ Plan 44(1):80-99

Willing R, Pojani D (2017) Is the suburban dream still alive in Australia? Evidence from Brisbane. Austr Plan 54(2):67-79

Wolman H, Galster G, Hanson R, Ratcliffe M, Furdell K, Sarzynski A (2005) The fundamental challenge in measuring sprawl: which land should be considered? Prof Geogr 57(1):94-105

Wu T, Yang S, Liu M, Qiu G, Li H, Luo M, Jia P (2020) Urban sprawl and childhood obesity. Obes Rev 22:10. https://doi.org/10.1111/obr.13091

You H, Yang X (2017) Urban expansion in 30 megacities of China: categorizing the driving force profiles to inform the urbanization policy. Land Use Policy 68:531-551 